\title{
Microbial and Plant Assisted Synthesis of Cobalt Oxide Nanoparticles and Their Antimicrobial Activities
}

\author{
Nadia Mubraiz ${ }^{1}$, Asghari Bano ${ }^{2, *}$, Tariq Mahmood ${ }^{3}$ and Naeem Khan ${ }^{4, *}$ (D) \\ 1 Department of Plant Sciences, Quaid-I-Azam University, Islamabad 45320, Pakistan; \\ nadiamubariz@gmail.com \\ 2 Department of Biosciences, University of Wah, Wah Cantt 47000, Pakistan \\ 3 Nano Sciences and Catalyst Division, National Centre of Physics, Quaid-I-Azam University, \\ Islamabad 45320, Pakistan; tariqm20002000@yahoo.com \\ 4 Department of Agronomy, Institute of Food and Agricultural Sciences, University of Florida, \\ Gainesville, FL 32611, USA \\ * Correspondence: banoasghari@gmail.com (A.B.); naeemkhan@ufl.edu (N.K.)
}

Citation: Mubraiz, N.; Bano, A.; Mahmood, T.; Khan, N. Microbial and Plant Assisted Synthesis of Cobalt Oxide Nanoparticles and Their Antimicrobial Activities. Agronomy 2021, 11, 1607. https://doi.org/ 10.3390/agronomy11081607

Academic Editor: Jesús Martín-Gil

Received: 27 June 2021

Accepted: 9 August 2021

Published: 12 August 2021

Publisher's Note: MDPI stays neutral with regard to jurisdictional claims in published maps and institutional affiliations.

Copyright: (c) 2021 by the authors. Licensee MDPI, Basel, Switzerland. This article is an open access article distributed under the terms and conditions of the Creative Commons Attribution (CC BY) license (https:// creativecommons.org/licenses/by/ $4.0 /)$.

\begin{abstract}
The development of sustainable, ecofriendly, and cost-effective methods for the synthesis of nanomaterials is an important aspect of nanotechnology these days. The present study was aimed at synthesizing cobalt oxide $\left(\mathrm{Co}_{3} \mathrm{O}_{4}\right)$ nanoparticles by using plant extracts of Aerva javanica, bacterial isolates from rhizospheric soil of Potentilla atrosanguinea, Swertia petiolata, Senecio chrysanthemoides, and from fungus Fusarium oxysporum. X-ray diffraction spectroscopy (XRD) and scanning electron microscopy (SEM) techniques were used in the characterization of the synthesized nanoparticles. The bacterial strain, Bacillus subtilis, isolated from rhizosphere of Potentilla atrosanguinea (N1C1), Fusarium oxysporum, methanolic and aqueous extracts of Aerva javanica reduced the cobalt salts to cobalt oxide nanoparticles. The nanoparticles, synthesized from bacterial isolate N1C1 (Bacillus subtilis) and from Fusarium oxysporum had average particle size of $31.2 \mathrm{~nm}$ and $33.4 \mathrm{~nm}$, respectively, whereas, the particle size of Aerva javanica was higher $(39.2 \mathrm{~nm})$ and all the nanoparticles were poly shaped. The nanoparticles synthesized from methanolic extract of Aerva javanica, bacterial strain (N1C1) and fungi Fusarium oxysporum showed better performance against Bacillus subtilis and P. aeruginosa, the bactericidal activity was higher against Gram-positive bacterial strains. Methanolic extracts of leaf and flower have shown a wide range of phytochemicals and higher antibacterial activity, and among all strains, Pseudomonas aeruginosa and Bacillus subtilis susceptibility was greater to extracts.
\end{abstract}

Keywords: cobalt oxide nanoparticles; antimicrobial activity; Fusarium oxysporum; Aerva javanica; scanning electron microscopy; X-ray diffraction spectroscopy

\section{Introduction}

Nanoscience is one of the fastest developing multi-disciplinary fields, which holds a promising future because of the close relationship between basic and applied aspects of this field [1]. Nowadays, different types of nanoparticles are synthesized by using many physical, chemical, biological, and hybrid methods [2]. Biosynthetic methods employing either biological microorganism such as bacteria [3], fungus [4], and plant extracts [5] have proven to be simple and viable substitutes to more complex chemical synthetic procedures of obtaining nanomaterials. Different types of nanoparticles, such as copper, titanium, zinc [6], alginate [7], gold, magnesium, [8], and silver are synthesized. The most stable phase of cobalt oxide, $\mathrm{Co}_{3} \mathrm{O}_{4}$ is used in lithium-ion batteries, gas sensors, magnetic storage, and supercapacitors [9]. It is produced chemically through various methods like $13 \mathrm{~nm} \mathrm{Co} \mathrm{O}_{4}$ in crystal sizes were synthesized from reaction of $\mathrm{Co}\left(\mathrm{NO}_{3}\right)_{2}{ }_{2} 6 \mathrm{H}_{2} \mathrm{O}$ with $\mathrm{NH}_{4} \mathrm{HCO}_{3}$ at $300{ }^{\circ} \mathrm{C}$ [10]. Solanum trilobatum Linn extract was used for the synthesis of silver nanoparticles under different temperature ranges. Silver nanoparticles having 15-20 nm cubic and hexagonal shape were formed in sunlight [11]. The extract of Psidium 
guajava leaves indicated the involvement of its polar phytocompounds in reducing the metal source and stabilizing the nanoparticles. Therefore, the extract of its leaves was used in the fabrication of various nanoparticles such as, silver, gold, zinc, and copper oxide nanoparticles $[12,13]$. Rhizospheric microorganisms can improve plant performance under different types of stress environments and improve yield through direct and indirect mechanisms [14]. Various Bacillus species were used in the preparation of nanoparticles because of their easy handling and their ability to survive under low and high temperatures, and variable degrees of acidity and alkalinity [15]. It was found the Fusarium oxysporum shows high tolerance towards heavy metals [16]; also because of its growth rate, easy processing, and biomass production Fusarium oxysporum is used in rapid synthesis of nanoparticles [17]. Ahmad et al. [18] demonstrated the synthesis of 5-15 nm silver nanoparticles from Fusarium oxysporum. Various Fusarium oxysporum strains were involved in the production of nanoparticles ranging from 20 to $50 \mathrm{~nm}$. Das et al. [19] reported the production of nanoparticles of gold by using Rhizopus oryzae which were confirmed through Fourier-transform infrared spectroscopy (FTIR). Similarly, Mukherjee et al. [20] found biological production of silver nanocrystalline $35 \pm 10 \mathrm{~nm}$ particles from Trichoderma asperellum. Aspergillus tubingensis and Bionectria ochroleuca showed significant ability to form silver nanoparticles extracellularly. Further evaluation by X-ray diffraction analysis and photon correlation spectroscopy for particle size and zeta potential, showed effective antifungal activity against Candida sp. with minimal inhibitory concentration in the range of $0.11-1.75 \mu \mathrm{g} / \mathrm{mL}$ [21]. Aerva javanica is a plant species belonging to the family Amaranthaceae; native to Africa and also present in some Asian countries and many other parts of the world. It is a perennial herb [22]. Fusarium is a heterogeneous genus and is distributed all over the world [23]. Fusarium oxysporum belong to division Ascomycota and family Nectriaceae.

Research is now focused on green synthesis of nanoparticles because this biologicalbased process is not only environment friendly, cost effective, and rapid, but the chemically synthesized nanoparticles may also exhibit pharmacological residual effects on the ecosystem. So, for this reason, in metal nanoparticles production, microorganisms are also used [24]. The development of methods benign to the ecosystem for biogenetic production is now of more interest due to simplicity of the procedures and versatility [25,26]. Due to their amenability to biological functionalization, biological nanoparticles are receiving important applications in the field of medicine [27]. The biomolecules present in plant extracts can be used in the synthesis of nanoparticles through a single-step green synthesis process [28]. Beside this, biological synthesis using different plants and microbes results in stable production of nanoparticles with controlled sizes and shapes, the process is rapid, lacks complex chemical synthesis, and is nontoxic [29].

Secondly, the green synthesis of nanoparticles using biological material also facilitates their implication as biocontrol agents in addition to their growth promoting properties, for example, bacteria produce phytohormones and promote growth and development of plants when used as bioinoculant. Furthermore, their biocontrol potential gets enhanced when they are in nanoparticle form [30].

Cobalt oxide possesses interesting properties and therefore has attracted numerous researchers to studying their possible biomedical and agricultural applications [31]. Cobalt oxide nanoparticles show antibacterial, antioxidant, and antileishmanial effects where the biogenic cobalt oxides NPs showed DPPH free radical scavenging potential [32]. They can be used as a cofactor of vitamin B12, energy storage, and as a nanopesticide [33]. However, these NPs also show eco-toxic effects, though the toxicity mechanism of NPs is unknown but mostly depends on their shape, and physical and chemical properties [34]. The toxicity of Co-NPs may be characterized either by their direct uptake by cells or by their solubilized metal ions in the media [35]. The toxicity mechanisms have not yet been completely elucidated for most NPs, and little is known about the potential effects of plants and NPs on their subsequent fate in the food chain [36]. Hence, NPs ought to be designed to have all necessary properties such as effective concentration with high effectiveness, stability, 
solubility, time-controlled release in response to certain stimuli, enhanced targeted activity, and less toxicity with safe and easy mode of delivery to avoid repeated applications [37].

Microorganisms like bacteria usually display a process called bioreduction, which includes the accumulation of metallic ions to decrease their toxicity. Plants also possess the reducing capability because of the presence of various biomolecules in their extracts [38]. Both plant extracts and microbial cells are known to contain many compounds such as, polysaccharides, proteins, amino acids, organic acids, and phytochemicals such as, polyphenols, flavonoids, terpenoids, alkaloids, tannins, and alcoholic substances can reduce and stabilize the nanoparticles and causes their synthesis $[39,40]$. Fungi are excellent sources of many bioactive compounds that can be used in the synthesis of nanoparticles. The microscopic filamentous fungi and other fungal species are reported to produce thousands of bioactive compounds [41]. These microorganisms possess lenience to the heavy metals and can adopt as well as bioaccumulate the metals. Thus, these organisms have been used for reduction and stabilization during the synthesis of nanoparticles. Fungi are more convenient compared to other microbes due to their production of high quantities of enzymes and proteins for nanoparticle synthesis [42,43]. Since fungi are very effective secretors of extracellular enzymes, therefore achieving vast production of enzymes is feasible [44] and can produce nanoparticles and nanostructure via reducing enzyme intracellularly or extracellularly. Microbes-nanoparticle interactions play a significant role in disease treatment in the form of antimicrobial agents as biological nanoparticles were found to be more pharmacologically active than physico-chemically synthesized nanoparticles [45]. The inhibitory mechanism of nanoparticles against different pathogenic bacteria and fungi includes release of metal ions that interact with cellular components through various pathways including reactive oxygen species (ROS) generation, pore formation in cell membranes, and cell wall damage that ultimately inhibits the growth of cells [46]. Nanomaterials as antibacterial complements to antibiotics are highly promising and are gaining large interest as they might fill the gaps where antibiotics frequently fail $[47,48]$.

The chemical synthesis of nanoparticles has several potential environmental hazards and causes carcinogenicity, genotoxicity, cytotoxicity, and general toxicity [49]. Use of toxic compounds also limits their applications. Hence, green synthesis of nanoparticles using biological materials viz. plants, bacteria, and fungi is more sustainable, ecofriendly, and cost effective. The novelty of using plants and bacteria is their additional benefit as having medicinal properties such as, antifungal, and antibacterial properties; in the case of plants against pathogens, the bacteria used for synthesis of nanoparticles may have biocontrol potential. Therefore, the present investigation is based on the hypothesis that the production of nanoparticles from plants and bacteria impart biocontrol properties in addition to their growth promoting properties and phytohormone producing potential of plants and bacteria, based on which the current research was aimed at synthesizing ecofriendly nanoparticles from plant extracts, rhizobacteria, and fungi, and their subsequent characterization by XRD and SEM and application as antibacterial and antifungal agents against selected species of pathogenic bacteria and fungi.

\section{Materials and Methods}

The present research work was carried out in the Phytohormone Laboratory, Department of Plant Sciences, Quaid-i-Azam University, Islamabad, in collaboration with the National Centre for Physics (NCP), Islamabad, Pakistan. Aerial parts of the Aerva javanica were collected from Khalol, Tehsil Kahuta District, Rawalpindi. Fresh aerial parts were taken, rinsed with distilled water and shade dried. Dried material was ground, and $50 \mathrm{~g}$ powder was soaked in $500 \mathrm{~mL}$ of methanol and methanol: water in 1:1 ratio. The homogenized mixture was incubated for two weeks at room temperature $\left(25^{\circ} \mathrm{C}\right)$ with occasional shaking to facilitate extraction. The extract was filtered through double Whatman \#41 filter paper. The extracts were completely evaporated by rotary evaporator at $40^{\circ} \mathrm{C}$ and under reduced pressure. About $1.8 \mathrm{~g}$ of extract of Aerva was obtained. The extracts were stored at $4{ }^{\circ} \mathrm{C}$ in the refrigerator and further used for antibacterial and antifungal activities. 


\subsection{Isolation and Characterization of Bacterial Strains}

Three soil samples were collected from Gilgit at altitude of 3670 m.a.s.l. (from rhizosphere of Potentilla atrosanguinea, Family; Rosaceae), 3914 m.a.s.l. (from rhizosphere of Swertia Petiolata, Family; Gentianaceae), and 3486 m.a.s.l. (from rhizosphere of Senecio chrysanthemoides, Family: Apiaceae).

For isolation of bacterial strains, $1 \mathrm{~g}$ soil from each sample was mixed with $10 \mathrm{~mL}$ double-distilled water. The mixture was stored in an autoclavable Falcon tube and centrifuged at $3000 \mathrm{rpm}$ for $10 \mathrm{~min}$. Thereafter, $10 \mathrm{~mL}$ supernatant was collected from each Falcon tube and decimal dilutions were prepared. From decimal dilutions an aliquot $(80-100 \mu \mathrm{L})$ was used to spread on LB agar plate and were incubated at $30^{\circ} \mathrm{C}$ for $72 \mathrm{~h}$. To study the cell morphology of selected bacterial strains the protocol described by Miller et al. [50] was used. Bacterial cells were grown overnight in LB agar plates, and after $24 \mathrm{~h}$, color and shape of each isolated colony was observed under light microscope (Nikon, Japan) at $100 \times$ magnification.

The number of colonies per plate were counted and CFU was determined as suggested by James [51].

$$
\mathrm{CFU}=(\text { colony count on an agar plate } / \text { total dilution of tube }) \times \text { dilution factor }
$$

Presence of oxidase enzymes in isolated microbial strains were checked according to Steel [52]. For this purpose, Kovac's reagent was made by the addition of hot distilled water. A strip of filter paper was immersed in this reagent and then desiccated. Twenty-four-hourold bacterial colonies were transferred to filter paper. The color was changed from purple to dark brown within $30 \mathrm{~s}$, indicating the presence of oxidase. Whereas, the catalase enzymes in microbial strains were detected according to Macfaddin [53]. Briefly, 24-h-old bacterial cultures were dropped on the slide following the addition of $30 \%$ hydrogen peroxide (1 drop). Catalases were recorded based on the existence of gas bubbles.

The QTS-24 miniaturized identification system (DESTO Laboratories Karachi, Pakistan) was used to examine the biochemical traits of selected isolates. The 24-h-old culture of bacterial colonies was suspended in saline solution $(0.85 \% \mathrm{NaCl})$ and was used to inoculate QTS kits.

\subsection{Extraction, Purification and Sequencing of Bacterial DNA}

A single colony of bacterial culture was used to inoculate tryptone yeast extract (TY) broth. The grown culture was centrifuged at $12,000 \mathrm{rpm}$ at $4{ }^{\circ} \mathrm{C}$ for $(10 \mathrm{~min})$ followed by suspending in lysis buffer. The supernatant was transferred into a new tube followed by the addition of chloroform. The obtained DNA was dissolved in distilled water. The purity of DNA was assessed through nanodrop spectrophotometry $(260-280 \mathrm{~nm})$. The obtained DNA was amplified. The primer used for PCR-amplification has the nucleotide sequence as fd1 (AGAGTTTGATCCTGGCTCAG) and rd1 (AAGGAGGTGATCCAGCC). The amplified PCR products were electrophoresed on $1.2 \%(w / v)$ agarose gel with DNA ladder $(1 \mathrm{~kb})$ as molecular marker. The gel was stained with $0.01 \mathrm{~g} / \mathrm{mL}$ ethidium bromide and examined under UV trans-illuminator lamp. Approximately $1400 \mathrm{bp}$ purified PCR products were sequenced by using primers 27FAgAgTTTgATCMTGGCTCAg, 1492RTACggYTACCTTgTTACgACTT, 518FCCA gCAgCCgCggTA ATA Cg, and 800R TAC CAgggT ATC TAA TCC. Sequencing products were resolute on an Applied Biosystems model 3730XL automated DNA sequencing system (Applied BioSystems, San Francisco, CA, USA) at the Macrogen, Inc., Seoul, South Korea.

\subsection{Characterization of Phytochemical by Thin Layer Chromatography}

Thin layer chromatography was performed on $20 \times 20 \mathrm{~cm}$ preparative silica gel plates (Merck, 25 Chromatofolios AL TLC $20 \times 20 \mathrm{~cm}$ Silica gel $60 \mathrm{~F}_{254}$ ). The flavonoid compounds present in Aerva javanica were qualitatively determined with the help of thin layer chromatography. Ultraviolet light was used to observe colored spots on the TLC 
chromatogram. Chloroform and methanol (9:1 ratio and 4:1) were used as mobile phase. Rf value was calculated by using the following formula [54].

$$
\mathrm{Rf}=\text { distance spot travel/total distance travel }
$$

\subsection{Synthesis of Nanoparticles}

2.4.1. Synthesis from Plant

Aerial parts of the plant Aerva javanica $(50 \mathrm{~g})$ were powdered using an electric grinder. The powdered material $(25 \mathrm{~g})$ was suspended in $250 \mathrm{~mL}$ distilled water or methanol and kept for $3 \mathrm{~d}$ at room temperature. The mixture was filtered using Whatman \#41 double filter paper. Thereafter, $100 \mathrm{~mL}$ of the filtrate was mixed with $0.1 \mathrm{M}$ solution of cobalt chloride $(100 \mathrm{~mL})$ incubated for $3 \mathrm{~d}$ in the dark. A mixture of distilled water and cobalt chloride solution was used as control to establish that this mixture cannot reduce cobalt chloride to cobalt oxide nanoparticles. Thereafter, the three days' mixture was transferred to China dishes and placed in an oven overnight. Dark green material in dried form was obtained which was placed in a furnace for $5 \mathrm{~h}$ at $400{ }^{\circ} \mathrm{C}$ (Wisetherm, FH-05, Lilienthal, Germany). After calcination, black color nanoparticles were formed.

\subsubsection{Synthesis from Bacterial Strains}

LB broth $(400 \mathrm{~mL})$ extract was prepared in four $250 \mathrm{~mL}$ flasks. After autoclave, the flasks were placed at room temperature in a laminar hood and allowed to cool. A pure colony of each bacterial strain (14-48-h-old culture) was inoculated in broth and placed in a shaker. Then $100 \mathrm{~mL}$ of $0.1 \mathrm{M}$ cobaltous chloride solution was added at 1:1 ratio and incubated in a shaker for $3 \mathrm{~d}$, at $\mathrm{pH}$ 6.8-7. The sterile media mixed with cobaltous chloride solution was used as control to establish that the media components cannot reduce cobalt chloride into cobalt oxide nanoparticles. The microbes were killed by autoclaving at $121^{\circ} \mathrm{C}$. The water content in the mixture was removed by placing the flaks in an oven (Diagnostic medical service, DSO) at $100^{\circ} \mathrm{C}$ overnight. The residue left was transferred to a furnace (Wisetherm, FH-05, Lilienthal, Germany) for calcination at $40{ }^{\circ} \mathrm{C}$ for $5 \mathrm{~h}$. The nanoparticles in powder form thus obtained were converted into very fine particles.

\subsubsection{Synthesis from Fungus}

Fusarium oxysporum $(10 \mathrm{~mL})$ was inoculated with 7-d-old culture and was poured into $100 \mathrm{~mL}$ of $0.1 \mathrm{M}$ solution of cobaltous chloride and kept in an incubator for $3 \mathrm{~d}$ at $28^{\circ} \mathrm{C}$. The sterile media mixed with cobaltous solution was used as control to establish that the media components cannot reduce cobalt chloride into cobalt oxide nanoparticles. The $\mathrm{pH}$ of the mixture was 6.5. After $3 \mathrm{~d}$, the contents were autoclaved and filtered by using a suction pump (OF301, Herlev, Denmark) using membrane filter paper $(0.045 \mathrm{~nm})$. The filtrate was placed in an oven at $100{ }^{\circ} \mathrm{C}$ overnight and calcined at $400^{\circ} \mathrm{C}$ for $5 \mathrm{~h}$.

\subsection{Characterization of Nanoparticles}

Nanoparticles were suspended in DMSO by using a sonicator for $20 \mathrm{~min}$ with concentrations of $25 \mathrm{mg} / \mathrm{mL}, 15.5 \mathrm{mg} / \mathrm{mL}, 6.25 \mathrm{mg} / \mathrm{mL}, 3.1 \mathrm{mg} / \mathrm{mL}$, and $1.5 \mathrm{mg} / \mathrm{mL}$.

Nutrient broth medium was prepared for each test organism by dissolving $0.13 \mathrm{~g}$ of nutrient broth powder in $10 \mathrm{~mL}$ of distilled water in a small $50 \mathrm{~mL}$ conical flask and the $\mathrm{pH}$ was adjusted to 7.0. The flasks were plugged with a cotton plug and autoclaved at $121^{\circ} \mathrm{C}$ and $151 \mathrm{~b} / \mathrm{psi}$ for $20 \mathrm{~min}$. After sterilization, the broth medium was allowed to cool under aseptic conditions. The 24-h-old test microorganism was then added to the broth culture in flasks with the help of a sterile wire loop. This mixture was then placed in a shaker for $24 \mathrm{~h}$ so that the test organism could grow well.

The agar tube dilution method was used for antifungal activity of the extract as reported by Choudary et al. [55].

The morphology and size of particles were further determined by using XRD (X-ray diffraction pattern). The X-ray diffraction pattern of the particle powder was studied with 
PAN Netherland diffractometer (Model 3040/60 X pert PRO). The morphological studies were investigated by JSM5910 (JEOL, Tokyo, Japan) field emission electron microscopy.

\section{Results}

\subsection{Isolation and Biochemical Characterization of Microbial Isolates}

Initially many colonies were obtained of which four colonies from different samples such as, N1C1 strain isolated from the rhizosphere of Seneciochry santhemoides, Family: Apiaceae 3486 m.a.s.l., Gilgit, was identified as Bacillus subtilis with which it bears $99 \%$ similarity. Na7C4 strain isolated from rhizosphere of Swertia Petiolata, Family: Gentianaceae, 3914 m.a.s.l., Gilgit, and Na13C4 (strain from rhizosphere of Potentilla Atrosanguinea, Family; Rosaceae 3670 m.a.s.l., Gilgit).

Bacillus sp. (Na13C3) and Planococcus rifietoensis (Na13C4) were Gram positive and have round cell shape, whereas Bacillus subtilis (N1CI) and Arthrobacter. sp. (Na7C4) are rod shaped and Gram negative. The Planococcus rifietoensis (Na13C4) had CFU/g soil $14 \times 10^{3}$ and Bacillus subtilis $(\mathrm{N} 1 \mathrm{CI})$ had maximum CFU at $10^{7}$ dilutions $\left(5.8 \times 10^{7}\right)$. The morphological and biochemical characterization of isolated bacterial strains are presented in Table 1. All strains were oxidase and catalase positive.

Table 1. Morphological and biochemical characterization of isolated microbial strains from the soil samples taken at three different altitudes in Gilgit Baltistan, Pakistan. Microbial identification kits QTS-24 from Desto Laboratory, were used for biochemical tests.

\begin{tabular}{|c|c|c|c|c|c|}
\hline \multirow{2}{*}{ Reactions } & \multirow{2}{*}{ Tests } & \multicolumn{4}{|c|}{ Soil Samples } \\
\hline & & Bacillus sp. (Na13C3) & Planococcus rifietoensis (Na13C4) & Arthrobacter sp. (Na7C4) & Bacillus subtilis (N1C1) \\
\hline CS & Colony shape/color & large round/white & Round/orange & Round/yellow & Small round/white \\
\hline CES & Cell shape & Round & Round & Rod & Rod \\
\hline GS & Gram staining & + & + & - & - \\
\hline Oxid & Oxidase & + & + & + & + \\
\hline Cat & Catalase & + & + & + & + \\
\hline CFU & Colony forming unit & $4.5 \times 10^{7}$ & $9 \times 10^{3}$ & $14 \times 10^{3}$ & $5.8 \times 10^{7}$ \\
\hline \multicolumn{6}{|c|}{ QTS } \\
\hline ONPG & $\begin{array}{c}\text { Ortho nitrophenyl } \\
\beta \text {-D-galactopyranoside }\end{array}$ & - & + & + & - \\
\hline CIT & Sodium citrate & + & + & + & + \\
\hline MALO & Sodium malonate & + & + & + & + \\
\hline LDC & Lysine decarboxylase & + & + & + & + \\
\hline $\mathrm{ADH}$ & Arginine dihydrolase & + & + & + & + \\
\hline ODC & Ornithine decarboxylase & + & + & + & + \\
\hline $\mathrm{H}_{2} \mathrm{~S}$ & $\mathrm{H}_{2} \mathrm{~S}$ production & - & - & - & + \\
\hline URE & Urea hydrolysis & + & + & + & + \\
\hline TDA & Tryptophan deaminase & + & + & + & + \\
\hline IND & Indole & - & - & - & - \\
\hline VP & (Vogesproskauer) Acetion & - & - & - & - \\
\hline GEL & Gelatin hydrolysis & - & - & - & - \\
\hline GLU & Acidic from glucose & + & + & + & + \\
\hline MALT & Acid from maltose & + & - & + & + \\
\hline $\mathrm{NO}_{3} / \mathrm{N}_{2}$ & & + & + & + & + \\
\hline SUC & Acid from sucrose & - & - & - & + \\
\hline MANN & Acid from mannitol & - & - & - & + \\
\hline ARA & Acid from arabinose & + & + & + & + \\
\hline RHAM & Acid from Rhamnose & + & - & + & + \\
\hline SOR & Acid from sorbitol & - & - & - & + \\
\hline INOS & Acid from inositol & - & - & - & + \\
\hline $\mathrm{ADO}$ & Acid from adonitol & - & - & - & + \\
\hline MEL & Acid from Melibiose & - & - & - & - \\
\hline RAF & Acid from raffinose & - & - & - & - \\
\hline
\end{tabular}


QTS miniaturized identification tests results of these strains were compared against the standard species present in Bergey's Manual of Determinative Bacteriology. The isolated rhizobacteria Planococcus rifietoensis (Na13C4) and Arthrobacter sp. (Na7C4) positively utilized ONPG, CIT, MALO, LDC, ADH, and ODC, whereas Bacillus subtilis (N1CI) (isolated from the rhizosphere of Potentilla Atrosanguinea) and Bacillus sp. (Na13C3) showed positive results to all others except ONPG. Of four isolates, Bacillus sp. (Na13C3), Planococcus rifietoensis (Na13C4), and Arthrobacter sp. (Na7C4) showed negative reaction to SUC, MANN, SOR, INOS, ADO, and $\mathrm{H}_{2} \mathrm{~S}$ production while Bacillus subtilis (N1CI) was positive for these tests. All isolated microbial colonies were positive for UREA, TDA, GLU, $\mathrm{NO}_{3} / \mathrm{N}_{2}$, and ARA activity and negative for IND, VP, GEL, MEL, and RAF, for MALT and Rhamnose were positive except Na13C4 which was negative to Rhamnose utilization. The microbial isolate N1C1 showed better utilization of carbohydrates.

\subsection{Thin Layer Chromatography}

Thin layer chromatography of methanolic and methanol water extract of Aerva javanica showed the presence of flavonoids, tannins detected with the help of ultraviolet light. Rf value was calculated from colored bands that were only visible under ultraviolet light of low and high wavelength. The phytochemicals identified with the help of Rf value are shown in Figure 1 and Table 2.

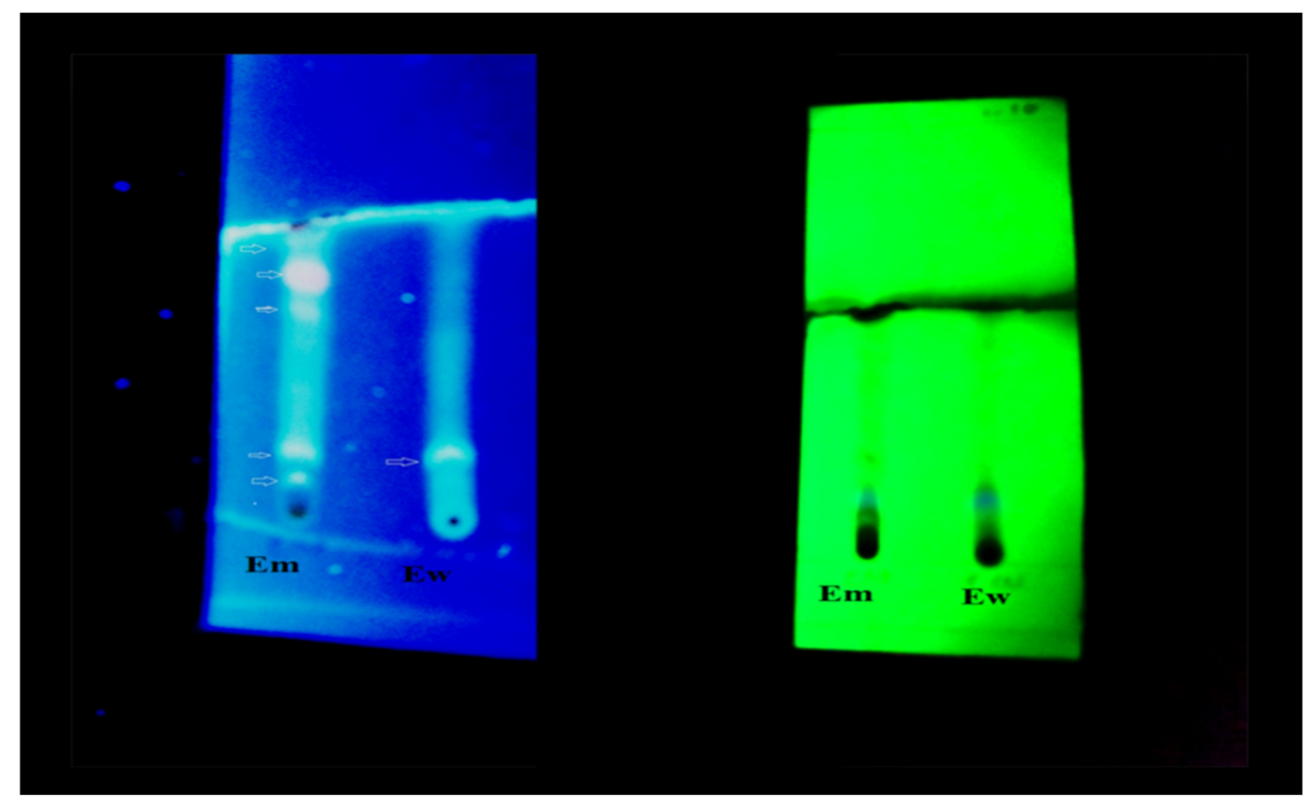

Figure 1. Thin layer chromatography of methanol and methanol:water extract of Aerva javanica with solvent media methanol:chloroform $(9: 1,4: 1)$.

Table 2. Phytochemicals identified through TLC (thin layer chromatography) in methanol and the methanol:water extracts of Aerva javanica.

\begin{tabular}{cccccc}
\hline \multirow{2}{*}{ Extracts } & Rf Value & Class of Compound & $\begin{array}{c}\text { Reported } \\
\text { Compounds }\end{array}$ & $\begin{array}{c}\text { Color of } \\
\text { Compound }\end{array}$ & References \\
\hline \multirow{2}{*}{ Ew } & 0.15 & & & & \\
\cline { 2 - 6 } & 0.68 & Tannins & & Bluish gray & [56] \\
\cline { 2 - 6 } & 0.511 & Flavonoid & Tectochrysin & Dark blue & - \\
\hline \multirow{2}{*}{ Em } & 0.444 & Flavonoids & Genkwanin & Bluish & - \\
\cline { 2 - 6 } & 0.57 & Flavonoids & Morin & Bluish & - \\
\cline { 2 - 6 } & 0.668 & Tannins & & Bluish gray & - \\
\hline & 0.8 & Flavonoids (365 nm) & Kaempferol & Light green & [57] \\
\hline
\end{tabular}




\subsection{Characterization of Nanoparticle}

Cobalt oxide $\left(\mathrm{Co}_{3} \mathrm{O}_{4}\right)$ nanoparticles synthesized from the plant, fungus, and bacteria were characterized through XRD and SEM. The XRD pattern of cobalt oxide synthesized from Fusarium oxysporum exhibited diffraction peaks at $30.9191^{\circ}, 36.5364^{\circ}, 59.0089^{\circ}$, and $64.9460^{\circ}$ at indices (220), (311), (511), and (440) according to standard JCPDS card No 01-080-1545. The highest peak was observed at $36.5364^{\circ}$ (311) indices. The peak's intensity showed the crystalline nature of the nanoparticle as presented in Figure 2. The average particle size was $33.4 \mathrm{~nm}$ (Table 3).

The XRD pattern of cobalt oxide synthesized from Fusarium oxysporum (Naf) exhibited diffraction peaks at $30.9191^{\circ}, 36.5364^{\circ}, 59.0089^{\circ}$, and $64.9460^{\circ}$ at indices (220), (311), (511), and (440) according to standard JCPDS card No 01-080-1545. The highest peak was observed at $36.5364^{\circ}$ at (311) indices. The peaks' intensity showed the crystalline nature of the nanoparticles as presented in Figure 2A. The average particle size was $33.4 \mathrm{~nm}$.

Table 3. Peak detail of XRD pattern of cobalt oxide synthesized from Fusarium oxysporum, bacterial species, methanolic extract of dried aerial part of Aerva javanica and water extract of dried aerial part of Aerva javanica.

\begin{tabular}{|c|c|c|c|c|c|c|}
\hline Source & $\begin{array}{l}\text { Pos. } \\
\left.\text { ( }{ }^{\circ} 2 \text { Th. }\right)\end{array}$ & $\begin{array}{l}\text { Height } \\
\text { (cts) }\end{array}$ & $\begin{array}{c}\text { Full-Width } \\
\text { Half-Maximum } \\
\left({ }^{\circ} \text { 2Th. }\right)\end{array}$ & d-Spacing ( & $\begin{array}{l}\text { Tip Width } \\
\left.\text { ( }{ }^{\circ} 2 \text { Th. }\right)\end{array}$ & Matched by \\
\hline \multirow{5}{*}{$\begin{array}{c}\text { Fusarium } \\
\text { oxysporum }\end{array}$} & 31.4981 & 508.56 & 0.2460 & 2.84033 & 0.2952 & 01-080-1543 \\
\hline & 36.5364 & 5426.86 & 0.1968 & 2.45940 & 0.2362 & 01-080-1543 \\
\hline & 44.821 & 27.25 & 0.1771 & 2.02110 & 0.2125 & 01-080-1532 \\
\hline & 59.0089 & 1526.73 & 0.1968 & 1.56538 & 0.2362 & 01-080-1543 \\
\hline & 64.9460 & 1814.11 & 0.3000 & 1.43471 & 0.3600 & 01-080-1543 \\
\hline \multirow{8}{*}{ Bacterial species } & 31.3115 & $15,451.40$ & 0.1968 & 2.85684 & & \\
\hline & 36.4362 & 2852.11 & 0.2460 & 2.46593 & & \\
\hline & 45.0464 & 5803.07 & 0.2460 & 2.01259 & & 01-080-1545 \\
\hline & 56.1684 & 1340.33 & 0.3444 & 1.63761 & & \\
\hline & 64.9833 & 356.50 & 0.6888 & 1.43516 & & \\
\hline & 65.9249 & 943.18 & 0.3936 & 1.41693 & & \\
\hline & 74.8941 & 1376.67 & 0.1968 & 1.26793 & & \\
\hline & 83.6190 & 557.20 & 0.7200 & 1.15547 & & \\
\hline \multirow{5}{*}{$\begin{array}{l}\text { Methanolic extract } \\
\text { of Aerva javanica }\end{array}$} & 31.2819 & 28.77 & 0.1771 & 2.85948 & 0.2125 & 01-080-1532 \\
\hline & 36.8551 & 118.44 & 0.1476 & 2.43886 & 0.1771 & 01-080-1532 \\
\hline & 44.8465 & 27.25 & 0.1771 & 2.02110 & 0.2125 & 01-080-1532 \\
\hline & 59.4016 & 33.83 & 0.2952 & 1.55597 & 0.3542 & 01-080-1532 \\
\hline & 65.1555 & 20.28 & 0.4320 & 1.43060 & 0.5184 & 01-080-1532 \\
\hline \multirow{5}{*}{$\begin{array}{l}\text { Water extract of } \\
\text { Aerva javanica }\end{array}$} & 28.5287 & 159.95 & 0.1033 & 3.12886 & & \\
\hline & 36.9674 & 35.99 & 0.2362 & 2.43171 & & 00-001-1152 \\
\hline & 40.6646 & 79.63 & 0.0886 & 2.21875 & & \\
\hline & 69.3668 & 8.34 & 0.2657 & 1.35480 & & \\
\hline & 73.9683 & 14.87 & 0.4320 & 1.28043 & & \\
\hline
\end{tabular}



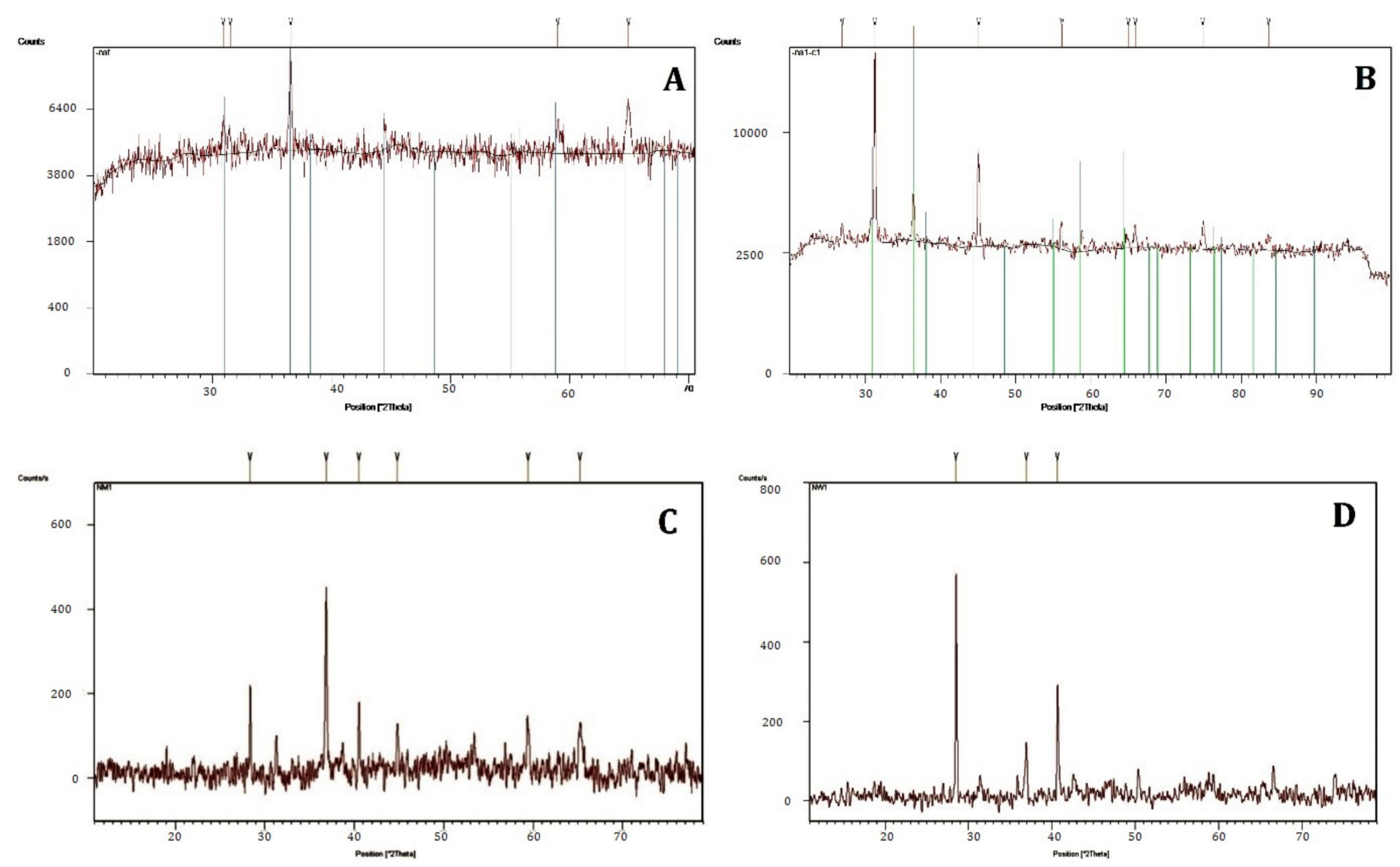

Figure 2. (A-D): X-ray diffraction spectroscopy (XRD) pattern of cobalt oxide synthesized from Fusarium oxysporum (A), bacterial strain N1C1 (B), aerial parts of Aerva javanica (C), and water extract of dried aerial parts Aerva javanica (D).

The XRD pattern of cobalt oxide nanoparticle synthesized from rhizobacterial isolate Bacillus subtilis (N1CI) showed diffraction peaks at $31.3115^{\circ}, 36.4362^{\circ}, 45.0464^{\circ}, 56.1684^{\circ}$, and $64.9833^{\circ}$. These peaks are consistent with the indices (220), (311), (400), (422), and (440) matched by standard JCPDS card 01-080-154 having particle size of $31.2 \mathrm{~nm}$. The particle size of $31.2 \mathrm{~nm}$ was calculated from the 1st, 3rd, and 5th peaks (Table 3). The peak with high intensity was at $31.3115^{\circ}$ showing the crystalline nature of nano powder (Figure 2B).

Similarly, cobalt oxide nanoparticles (Nm1) synthesized from methanolic extract of Aerva javanica showed reflection peaks at $31.278^{\circ}, 36.855^{\circ}, 36.855^{\circ}, 44.821^{\circ}, 59.371^{\circ}$, and $65.252^{\circ}$. These peaks correspond to indices (220), (311), (400), (511), and (440) matched by standard JCPDS card No 01-080-1532 and average size was $39.23 \mathrm{~nm}$ calculated from peaks 1, 3, and 5 (Table 3). The acute peak showed the cubic crystalline nature of material (Figure 2C).

The XRD pattern (Figure 2D) showed the formation of cobalt oxide from aqueous extracts of Aerva javanica representing the diffraction peaks at $36.963^{\circ}$ and $65.186^{\circ}$ at indices 311 and 440 corresponding to standard JCPDS card No 00-001-1152. The average particle size calculated from XRD pattern was $68.9 \mathrm{~nm}$ using the $1 \mathrm{st}$, 3rd, and 5 th peaks as shown in Table 3. The cobalt oxide nanoparticles synthesized from microbes were smaller in size than those of fungus and plant extracts. Methanolic extracts were smaller in size than those of aqueous extract.

SEM images of nanoparticles synthesized from isolated rhizobacterial strain, Bacillus subtilis (N1CI), and fungus, Fusarium moniliforme, are represented in Figures 3 and 4.

The synthesized nanoparticles were poly-shaped crystals at magnification of $0.5,1$, and $5 \mu \mathrm{m}$. All the particles were in cluster form.

\subsection{Antibacterial Activities of Bacterial Isolates, Plant Extract and Synthesized Nanoparticles}

The antibacterial activity of selected isolates, plant extracts, and nanoparticles synthesized from these isolates, plant extracts, and fungus were examined against four pathogenic 
strains viz. Bacillus subtilis, Staphylococcus aureus, Escherichia coli, and Pseudomonas aeruginosa at different concentrations.

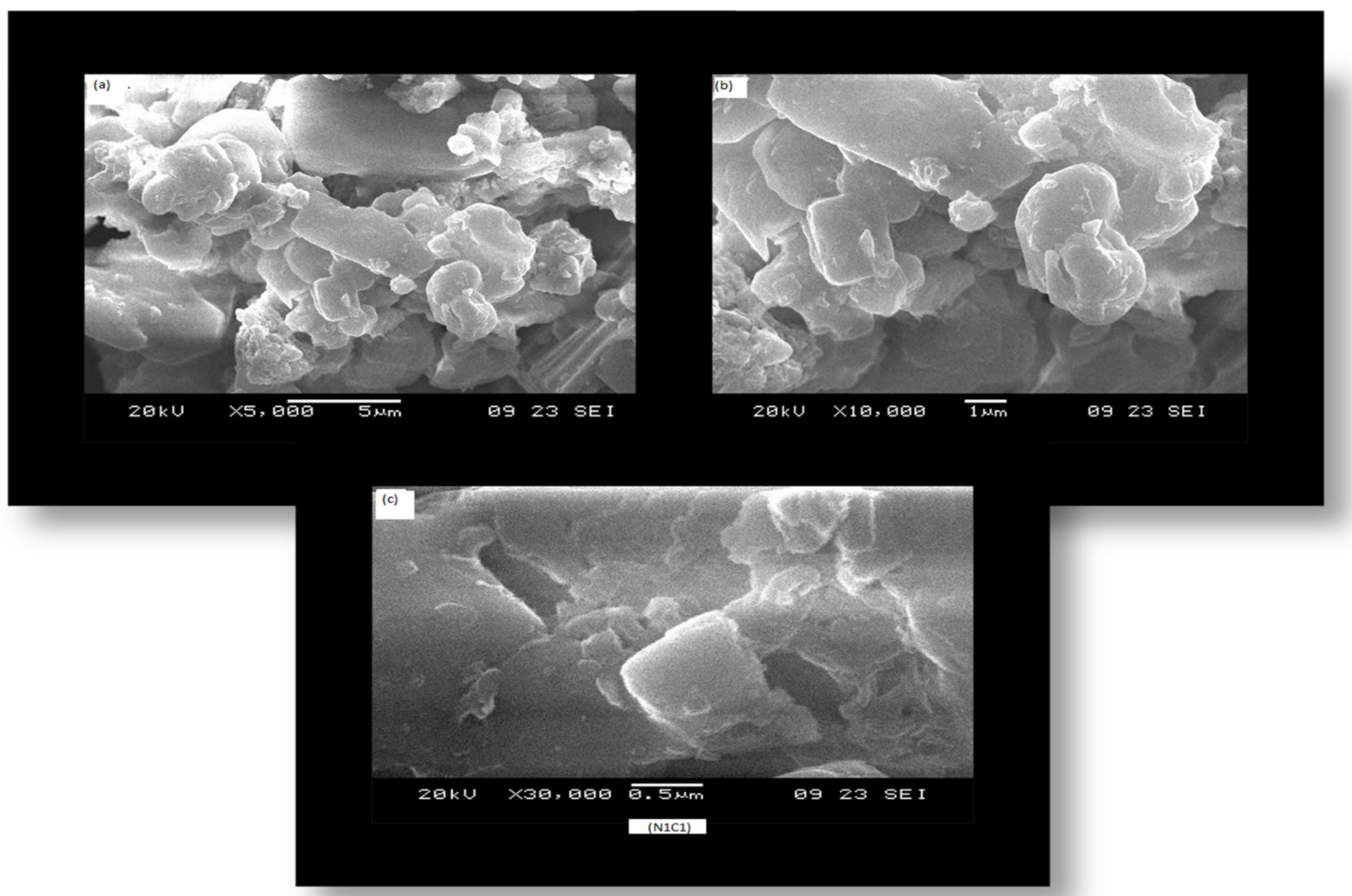

Figure 3. SEM images of cobalt oxide nanoparticles synthesized from N1C1 microbial strain isolated from soil at different magnifications.

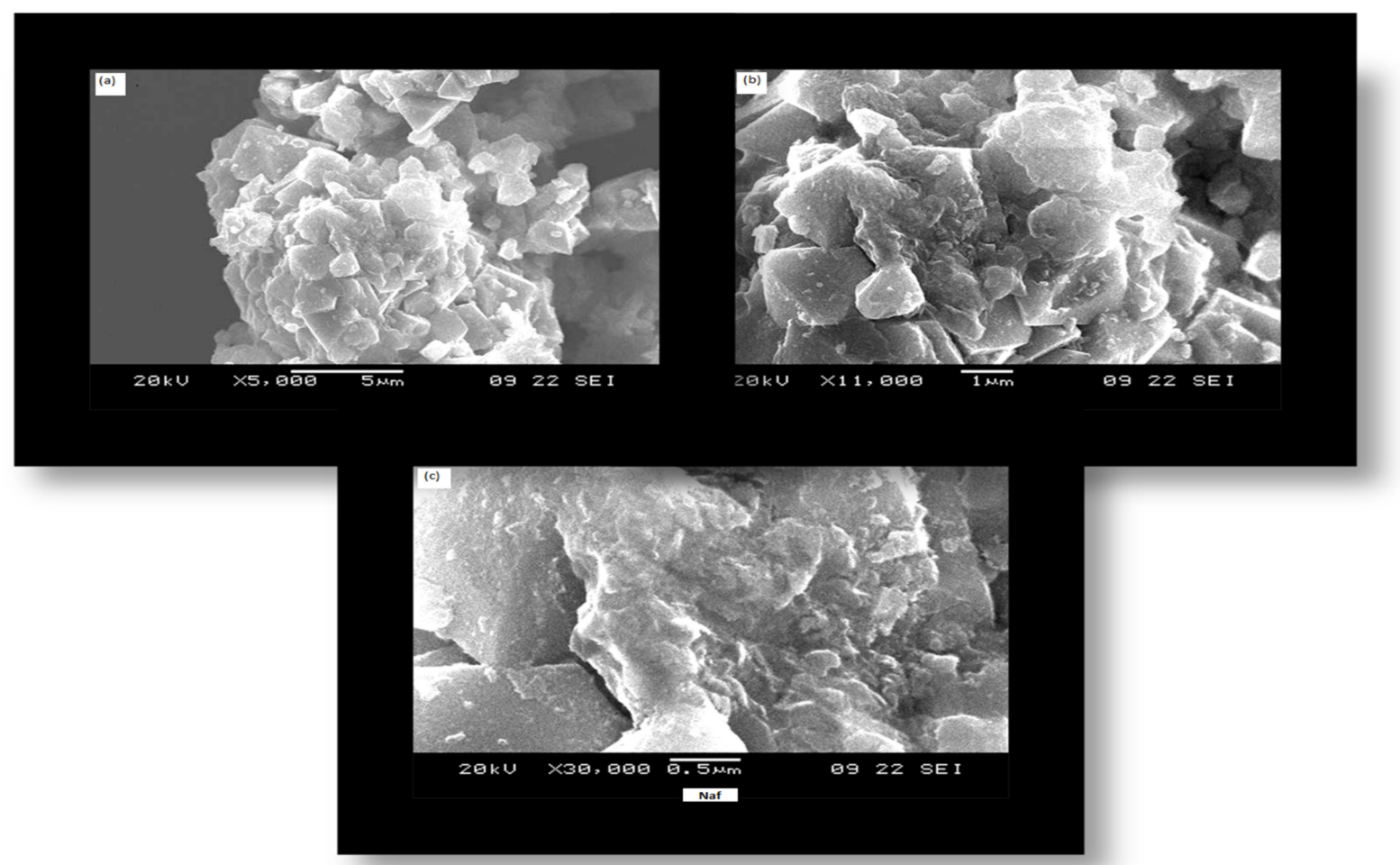

Figure 4. SEM images of cobalt oxide nanoparticles synthesized from Fusarium oxysporum. 
The maximum bactericidal activity against Bacillus subtitles was shown by N1C1 followed by Bacillus sp. (Na13C3) and Planococcus refietoensis (Na13C4). The Arthrobacter sp. (Na7C4) has no significant antibacterial activity against Bacillus subtilis. Significantly higher bactericidal activity against Staphylococcus aureus was exhibited by Arthrobacter sp. (Na7C4). Minimum antibacterial activity against Staphylococcus aureus was shown by Planococcus refietoensis (Figure 5).

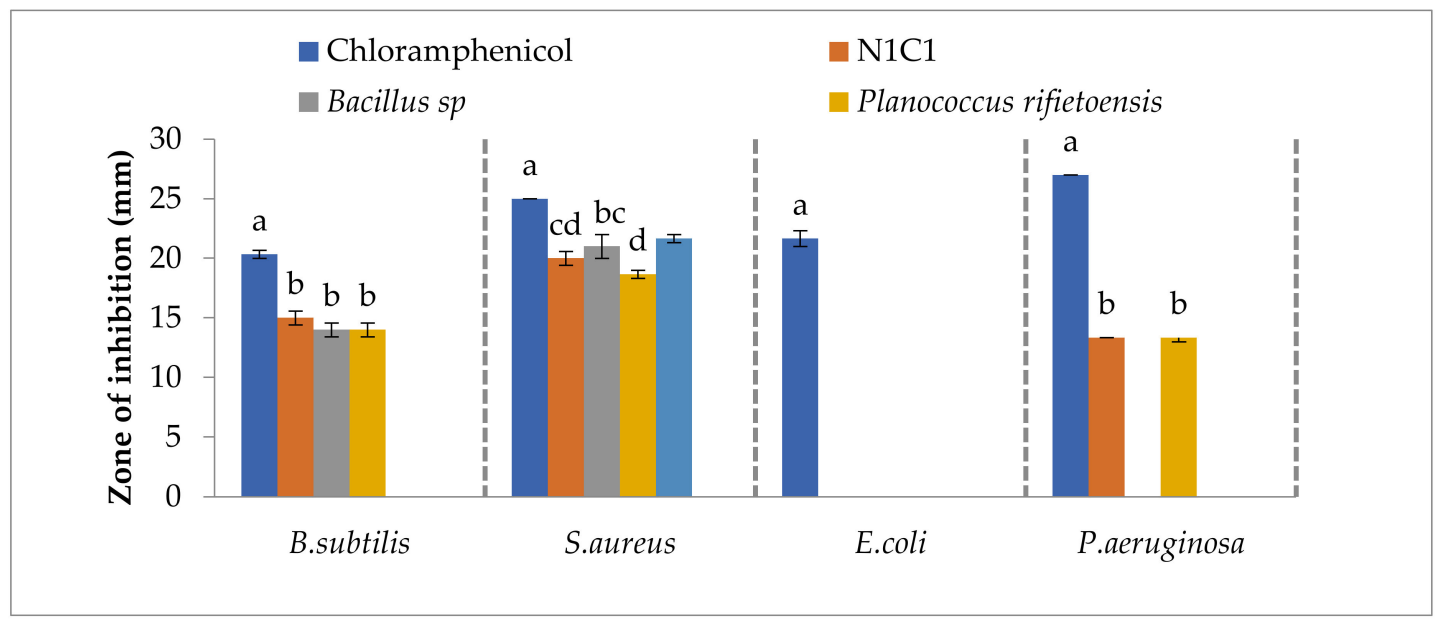

Figure 5. Antibacterial activity of Bacillus sp., Planococcus refietoensis, N1C1, and Arthrobacter sp. against pathogenic strains Bacillus subtilis, Staphylococcus aureus, Escherichia coli and Pseudomonas aeruginosa. Different letters are indicating significant differences $(p<0.05)$ among treatments.

Figures 6 and 7 showed that the plant methanolic and methanol:water (1:1) extracts exhibited concentration dependent bactericidal activity against pathogenic bacteria. The minimum inhibitory concentration (MIC) was $0.94 \mathrm{mg} / \mathrm{mL}$ against all pathogenic bacteria except for Escherichia coli where the MIC was $0.47 \mathrm{mg} / \mathrm{mL}$ in cases of methanolic extract while in the case of methanol:water the MIC was $0.94 \mathrm{mg} / \mathrm{mL}$ against Bacillus subtilis and Escherichia coli and $0.47 \mathrm{mg} / \mathrm{mL}$ against Staphylococcus aureus and Pseudomonas aeruginosa.

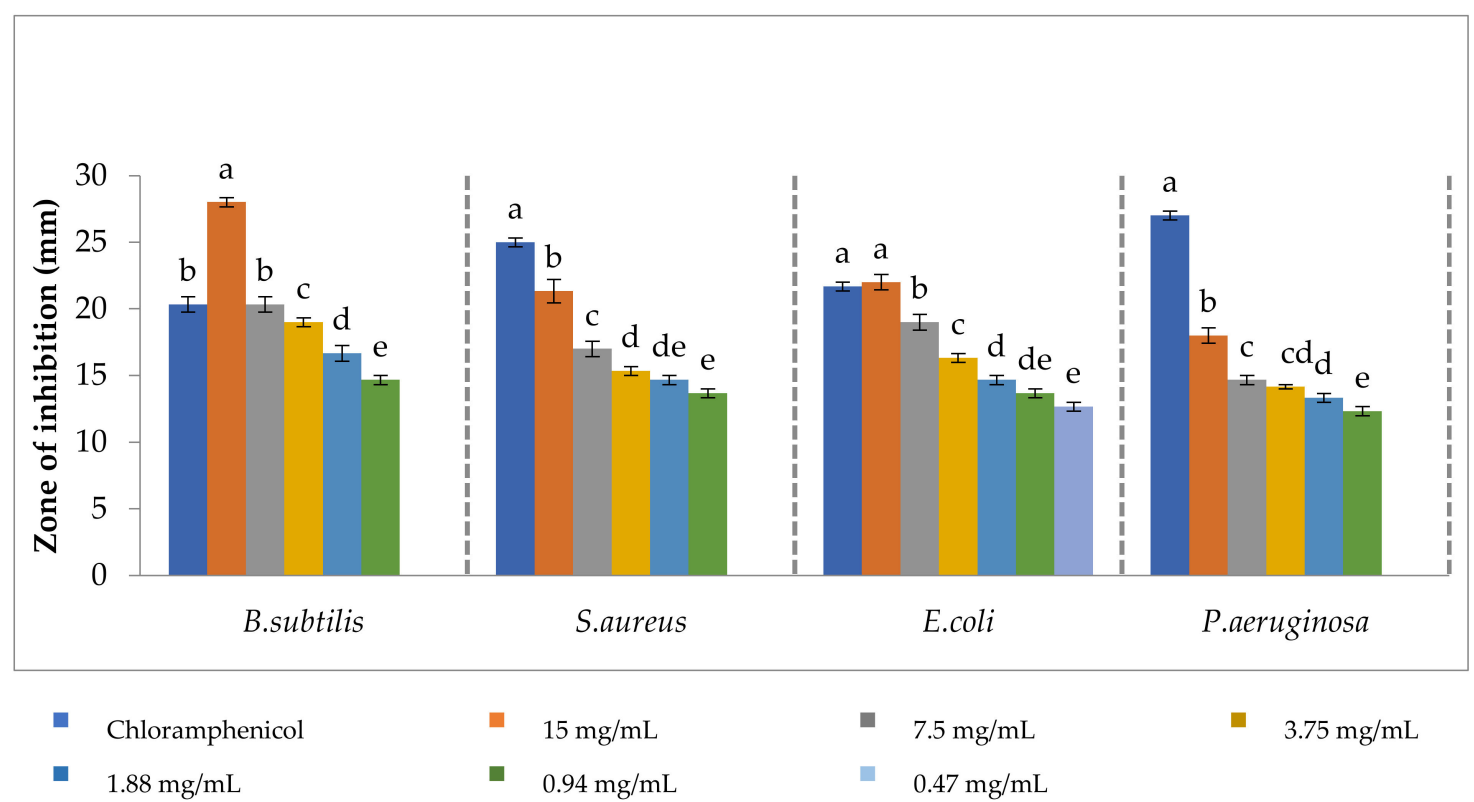

Figure 6. Antibacterial activity of methanolic extracts of aerial parts of Aerva javanica against pathogenic strains Bacillus subtilis, Staphylococcus aureus, Escherichia coli, and Pseudomonas aeruginosa at different concentrations. Different letters are indicating significant differences $(p<0.05)$ among treatments. 


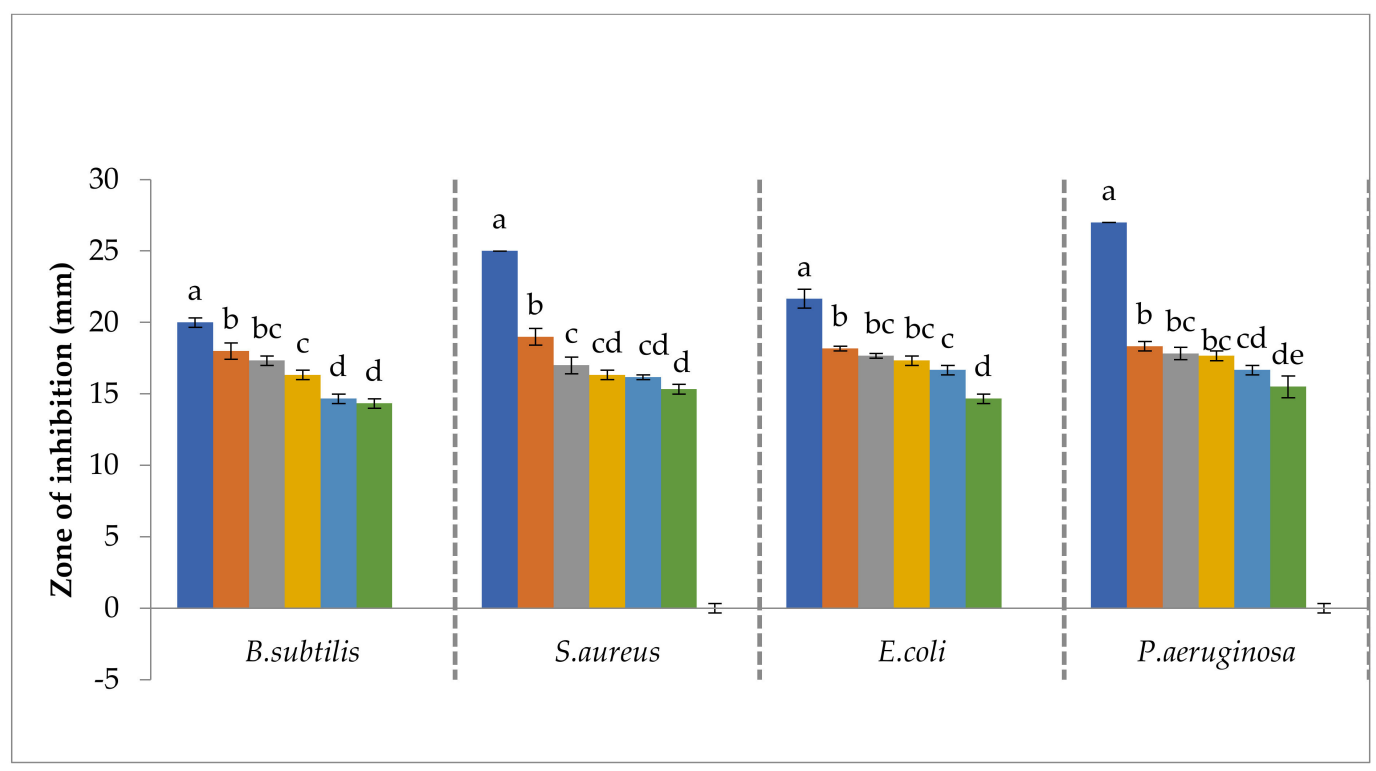

Figure 7. Antibacterial activity of methanolic:water (1:1) extracts of aerial parts of Aerva javanica against pathogenic strains Bacillus subtilis, Staphylococcus aureus, Escherichia coli, and Pseudomonas aeruginosa at different concentrations as shown in Figure 6. Different letters are indicating significant differences $(p<0.05)$ among treatments.

\subsection{Antibacterial Activity of Cobalt Oxide Nanoparticle}

Antibacterial activity of cobalt oxide nanoparticle synthesized from N1C1 microbial strain isolated from soil showed significantly higher inhibition potential at $25 \mathrm{mg} / \mathrm{mL}$ against all pathogenic strains which decreased with the decrease in concentration of the sample. Minimum inhibitory concentration of N1C1 nanoparticle against Bacillus subtilis, Escherichia coli, and Pseudomonas aeruginosa was $3.13 \mathrm{mg} / \mathrm{mL}$. For Staphylococcus aureus, MIC was $1.6 \mathrm{mg} / \mathrm{mL}$ nanoparticle (Figure 8).

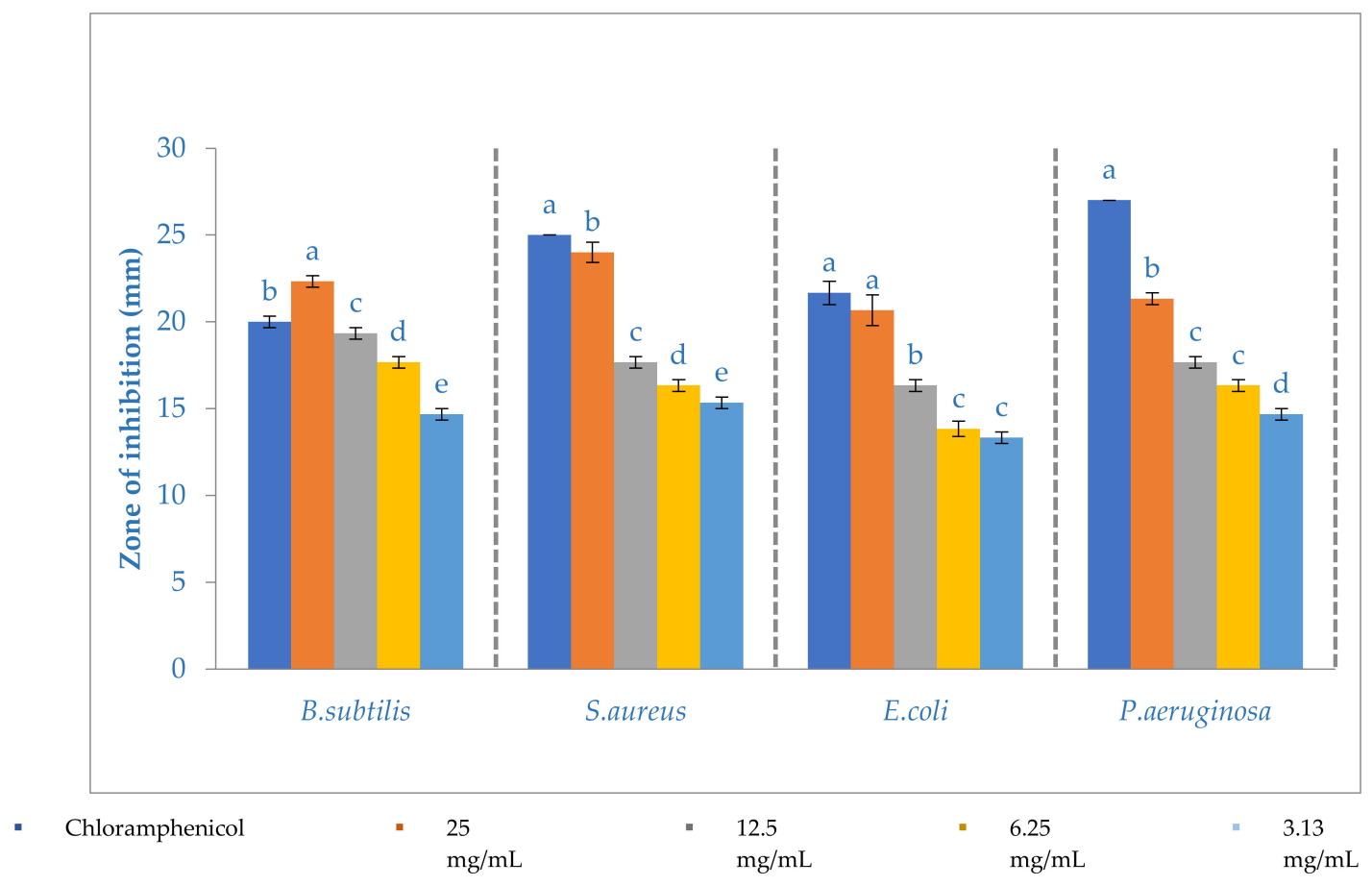

Figure 8. Antibacterial activity of nanoparticles (N1C1) synthesized from isolated microbial strain from soil of Gilgit at altitude of $3670 \mathrm{~m}$ (from rhizosphere of Potentilla atrosanguinea, Family; Rosaceae) against pathogenic strains Bacillus subtilis, Staphylococcus aureus, Escherichia coli, and Pseudomonas aeruginosa at different concentrations. Different letters are indicating significant differences $(p<0.05)$ among treatments. 
Nanoparticle synthesized from fungus Fusarium oxysporum showed significantly higher inhibition potential against all the pathogenic bacterial strains at higher concentration of $25 \mathrm{mg} / \mathrm{mL}$. Its MIC against Bacillus subtilis and Escherichia coli was $3.13 \mathrm{mg} / \mathrm{mL}$ while MIC recorded for Staphylococcus aureus and Pseudomonas putida was $1.6 \mathrm{mg} / \mathrm{mL}$ (Figure 9).

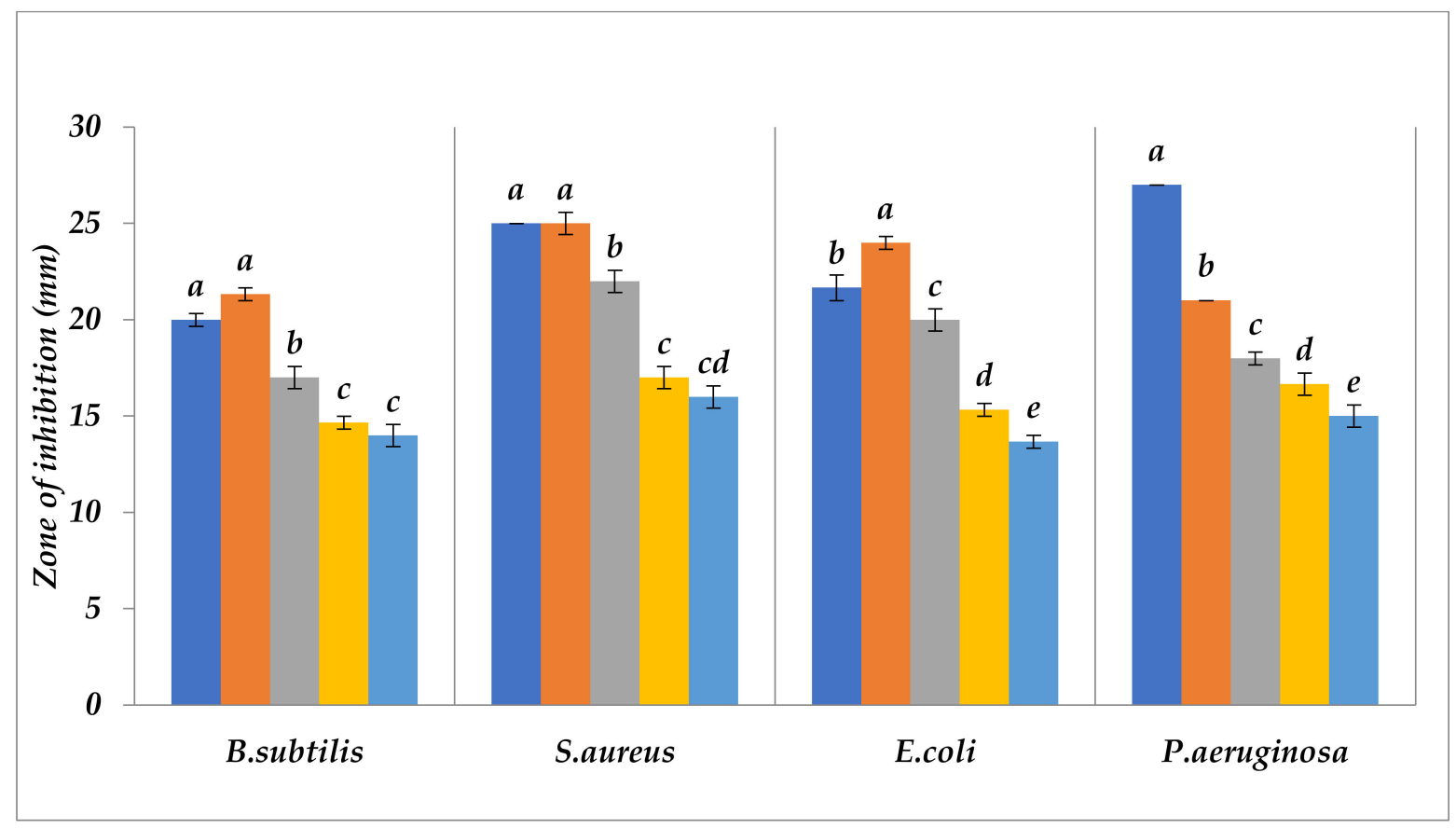

Figure 9. Antibacterial activity of cobalt oxide nanoparticles (Naf) synthesized from fungus Fusarium moniliforme against pathogenic strains at different concentrations as shown in Figure 8. Different letters are indicating significant differences $(p<0.05)$ among treatments.

Antibacterial activities of cobalt oxide nanoparticles synthesized from methanolic $(\mathrm{Nm})$ and aqueous extracts (Nw) of Aerva javanica are demonstrated in Figures 10 and 11. The nanoparticles synthesized by methanolic extract $(\mathrm{Nm})$ showed significantly higher antibacterial activity against all the strains at higher concentration; maximum inhibition was observed against Staphylococcus aureus than all other strains. Its minimum inhibitory concentration against Bacillus subtilis and Escherichia coli was in the range of $6.25-3.13 \mathrm{mg} / \mathrm{mL}$ against Staphylococcus aureus and Pseudomonas aeruginosa, respectively. While in the case of aqueous extract nanoparticles, the MIC was $6.25 \mathrm{mg} / \mathrm{mL}$ against Bacillus subtilis, $1.6 \mathrm{mg} / \mathrm{mL}$ against Staphylococcus aureus, $12.5 \mathrm{mg} / \mathrm{mL}$ against Escherichia coli, and $3.13 \mathrm{mg} / \mathrm{mL}$ against Pseudomonas aeruginosa. Nanoparticles showed good performance against Staphylococcus aureus followed by Pseudomonas aeruginosa.

\subsection{Antifungal Activities of Cobalt Oxide Nanoparticles}

The nanoparticles formed via methanol extract showed better performance in inhibiting (47\%) the growth of Fusarium moniliforme and mild activities (10\%) against Fusarium solani. Similarly, nanoparticles synthesized via fungus Fusarium oxysporum (Naf) showed $25.3 \%$ inhibition of Fusarium moniliforme growth and bacterial synthesized nanoparticles inhibited the growth of Fusarium solani by 20\% (Figure 12). 


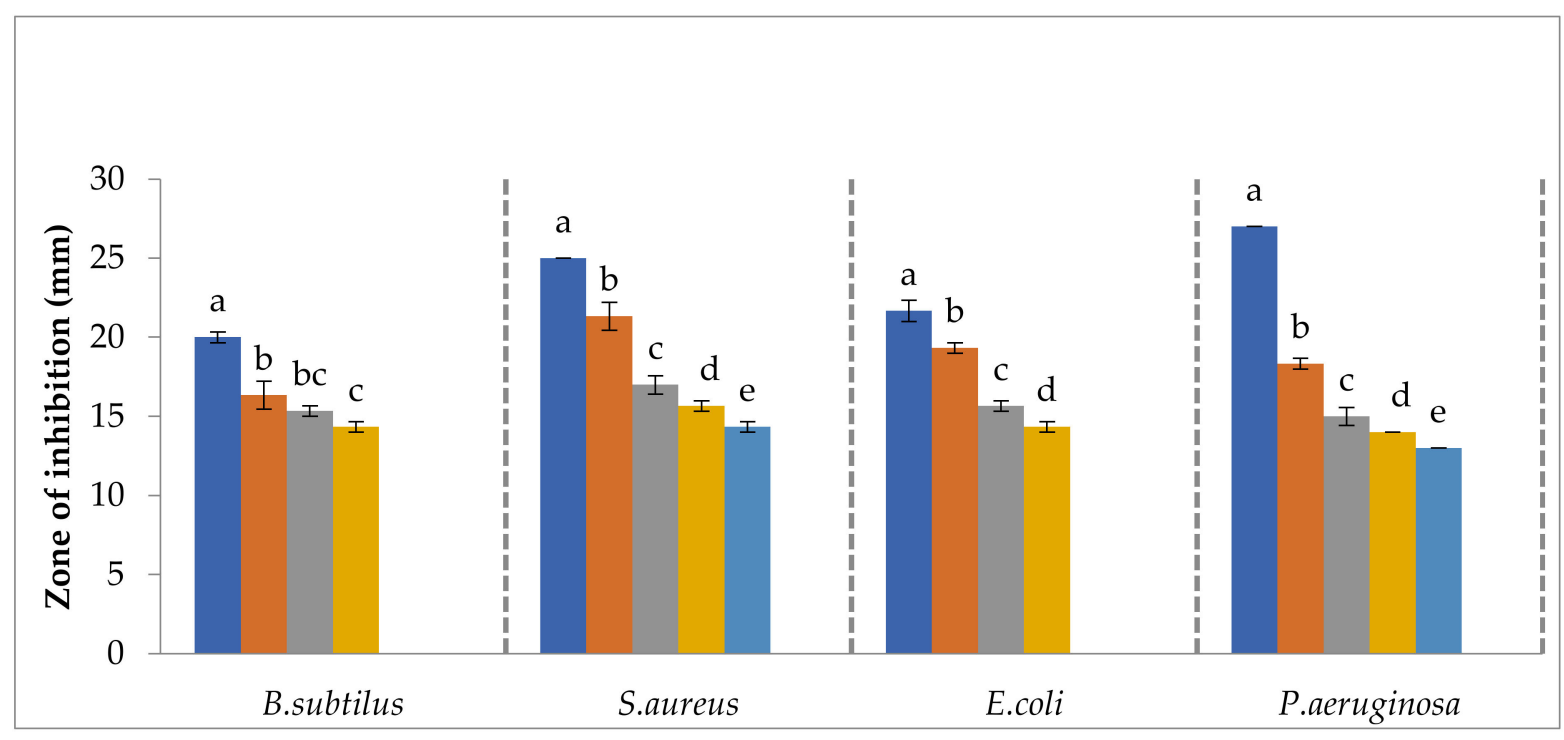

Figure 10. Antibacterial activity of nanoparticles (Nm) synthesized from methanolic extract of aerial parts of Aerva javanica against pathogenic strains Bacillus subtilis, Staphylococcus aureus, Escherichia coli, and Pseudomonas aeruginosa at different concentrations as shown in Figure 8. Different letters are indicating significant differences $(p<0.05)$ among treatments.

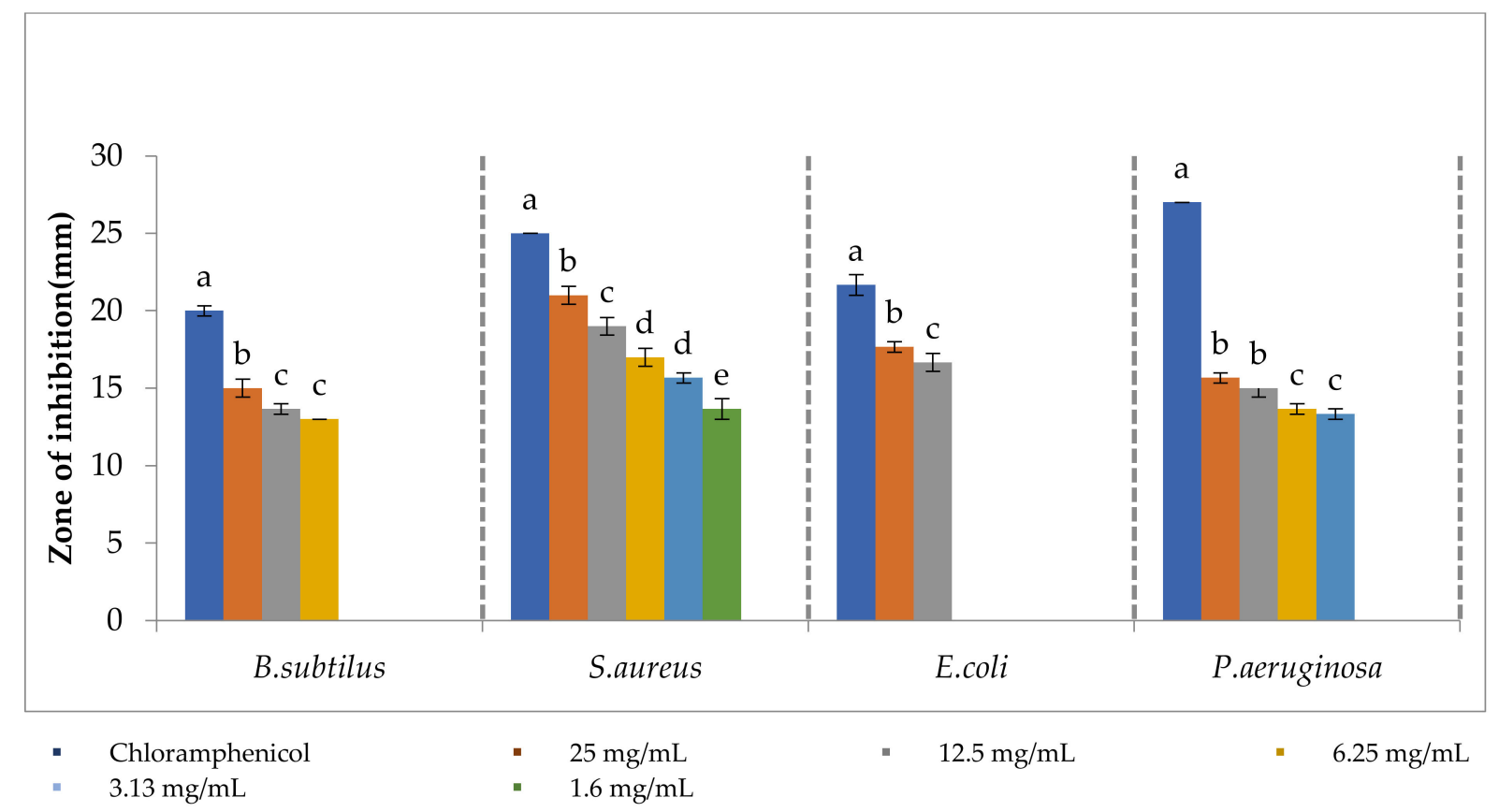

Figure 11. Antibacterial activity of nanoparticle (nw) synthesized from aqueous extract of aerial parts of Aerva javanica against pathogenic strains Bacillus subtilis, Staphylococcus aureus, Escherichia coli, and Pseudomonas aeruginosa at different concentrations. Different letters are indicating significant differences $(p<0.05)$ among treatments. 


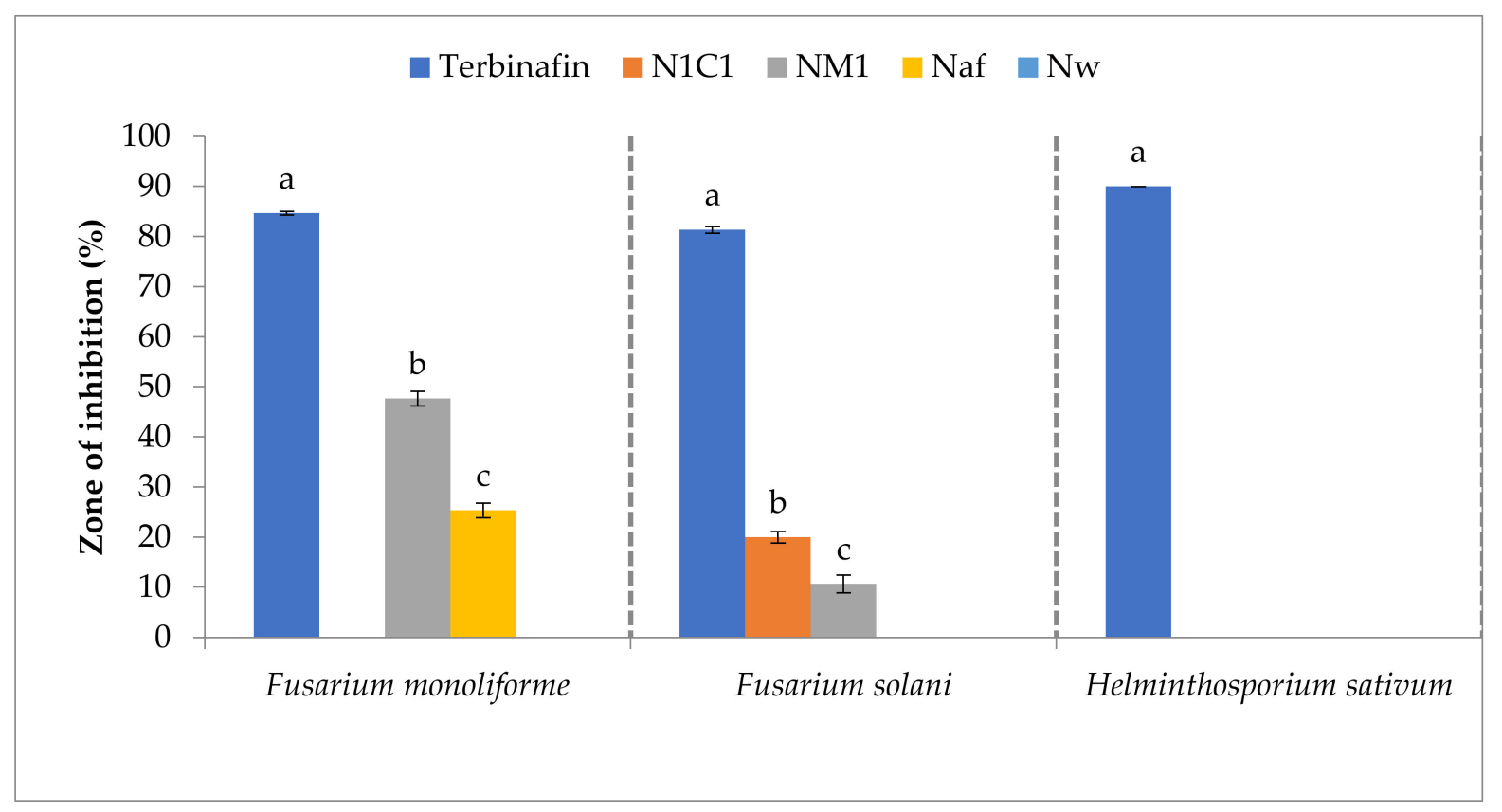

Figure 12. Antifungal activity of nanoparticles formed from bacterial strain N1C1, Fusarium oxysporum fungus, and methanolic and methanol water extracts of Aerva javanica $(16 \mathrm{~g} / \mathrm{mL})$ against Fusarium moniliforme, Fusarium solani, and Helminthosporium sativum. N1C1—Bacillus subtilis; NM1—methanolic extract of Aerva javanica; Naf-Fusarium oxysporum; $\mathrm{Nw}-$ Aqueous extract of aerial parts. Different letters are indicating significant differences $(p<0.05)$ among treatments.

\section{Discussion}

During current studies, potential of rhizobacteria isolated from rhizosphere of wild plants growing at higher altitude in Gilgit-Baltistan, methanolic and aqueous extracts of wild plant Aerva javanica and already identified fungus Fusarium oxysporum was assessed for the synthesis of cobalt oxide nanoparticles. The synthesized nanoparticles were characterized by XRD and SEM and evaluated for biological activities. Four microbial strains (Bacillus sp (Na13C3), Planococcus Rifietoensis (Na13C4), Arthrobacter sp. (Na7C4), and $\mathrm{N} 1 \mathrm{C} 1$ ) were used to synthesize cobalt oxide by reducing cobalt from cobalt chloride to cobalt oxide because $\mathrm{Co}_{3} \mathrm{O}_{4}$ is the most stable form. During current studies, only bacterial isolate Bacillus subtilis (N1CI) was capable of synthesizing cobalt oxide, which was confirmed through XRD pattern. These results confirmed the previous findings of He et al. [58] who used Rhodopseudomonas capsulata and synthesized gold nanoparticles of different sizes and shapes. Most metal ions are toxic for bacteria, hence bacteria use different strategies, e.g., bioreduction of ions or the formation of water insoluble complexes to overcome such toxicity [32], because for the synthesis of a specific nanoparticle, the microbe should be resistant to that metal. The failure of Bacillus sp. (Na13C3), Planococcus rifietoensis (Na13C4), and Arthrobacter sp (Na7C4) in the synthesis of nanoparticles may be attributed to their susceptibility towards metal toxicity because various metals are toxic to many microorganisms $[59,60]$. However, a good number of bacteria are resistant to heavy metals and improve their resistance towards metal toxicity. This important characteristic helps bacteria in their growth in media having high metal concentrations and has potential for nanoparticle's synthesis [61].

The average size of N1C1 calculated using XRD diffraction peaks was $31.2 \mathrm{~nm}$. Similarly, the particle size of cobalt oxide nanoparticle formed by fungus Fusarium oxysporum (Naf) was $33.4 \mathrm{~nm}$. Duran et al. [62] used several Fusarium oxysporum strains to synthesize $15-50 \mathrm{~nm}$ silver nanoparticles. Nanoparticle's size was dependent on $\mathrm{pH}$, incubation time, etc., which was altered by changing these conditions [63].

Nanoparticles produced from methanolic and aqueous extracts of Aerva javanica have an average size of $39.23 \mathrm{~nm}$ and $68.9 \mathrm{~nm}$. Presence of carbohydrates and protein in Aerva 
Javanica [64] might be a source of oxidation of cobalt-to-cobalt oxide nanoparticles [65]. In addition, presence of flavonoids also helps in the synthesis of nanoparticles. Plants contain many phytochemicals (terpenoids, flavones, ketones, aldehydes, amide, carboxylic acids, etc.) that may be helpful in reduction of metal ions into nanoparticles [66]. Presence of flavonoids in the Aerva javanica extracts were also confirmed through thin layer chromatography. Raghunandan et al. [67] reported that leaves extracted from Psidium guajava contained flavonoids involved in reduction of gold from gold chloride for the biosynthesis of poly-shaped gold nanoparticles.

The synthesized nanoparticles were poly-shaped crystals at magnification of $0.5,1$, and $5 \mu \mathrm{m}$ in scanning electron microscopy (SEM). Rod-shaped crystal nanoparticles were prominent in microbes while more or less cubic form was observed in fungus. Formation of different shapes like random and multifaceted structures were due to the aggregation processes [68-70]. Various mechanisms are involved in aggregation of particles such as agglutination (clumping of particles), cohesion, coagulation, condensation, etc. Many factors such as diffusion time and reaction time are involved in controlling the size and shape of aggregates [71].

During current studies, methanolic extract of Aerva javanica had greater antibacterial activity against all the tested bacterial strains. However, the bactericidal activity was higher against Gram-positive bacterial strains. Plant methanolic and methanol:water (1:1) extracts exhibited concentration-dependent bactericidal activity against pathogenic bacteria. The plant, fungal, and bacterial extracts were more effective against pathogenic bacteria than the pathogenic fungi. Results further demonstrate that the methanol:water extract of plant-based nanoparticles was effective and at $15 \mathrm{mg} / \mathrm{mL}$ can supersede even the standard antibiotic chloramphenicol. Antifungal activity of methanolic extract of plant-based nanoparticles was effective and can supplement the fungicide. Mothana et al. [72] examined the 64 methanol and water extracts of thirty Yemeni plants (Cupressus sempervirens) in which prominent antimicrobial activity was observed against Gram-positive bacteria. Srinivas and Reddy [73] also demonstrated that the amount of Aerva javanica residues extracted with methanol was higher when compared with other solvents and leaf and flower yielded larger amounts of extracts. Methanolic extracts of leaf and flower have shown a wide range of phytochemicals and higher antibacterial activity and among all strains, Pseudomonas aeruginosa and Bacillus subtilis susceptibility was greater to extracts [74].

The antibacterial activity of the synthesized nanoparticles was dependent on their source of reducing agents. The nanoparticles synthesized from methanolic extract of Aerva javanica, bacterial strain (N1C1), and fungi Fusarium oxysporum showed better performance against Bacillus subtilis and P. aeruginosa. S. aureus was more susceptible to Naf. Nidhi et al. [75] reported that the silver nanoparticles synthesized from Cynodon dactylon leaves were most effective against $P$. aeruginosa followed by S. aureus, E. coli, and S. typhimurium. The nanoparticles illustrated mild antibacterial effects against Gram-negative E. coli and S. typhimurium but significant activity against Gram-positive S. aureus and Gram-negative P. aeruginosa. Members of genera Fusarium and Helminthosporium were well known phytopathogens producing major losses in crop yield; keeping the importance of this economic damage in mind it was very fascinating to test the antifungal potential of isolates (Arthrobacter sp. (Na7C4), Bacillus sp. (Na13C3), Planococcus rifietoensis (Na13C4), and N1C1)), plant extracts (methanolic and methanol water), and their nanoparticles and nanoparticles formed from fungus against these pathogenic fungal strains. Plant methanolic extract inhibited the growth of Fusarium moniliform, Fusarium solani, and Helminthospore sativum with greater percentage than other samples. Plants are an important source of fungal toxic compounds, and they may provide renewable sources of useful fungicides that can be utilized in antimycotics drugs against different fungus. Cespedes et al. [76] reported that methanolic extract showed good antifungal activity against Fusatium moniliforme and other fungal species. Among microbes, Fusarium moniliforme was encountered by Bacillus sp in a better way than others while Arthrobacter sp and N1C1 showed mild activity and Planococcus refietoensis did not inhibited the growth of fungus. Bascillus sp's 
performance against pathogenic strains suggested that it has the potential for promotion of plant growth and suppression of soil-borne plant pathogens. This statement is supported by Svanstrom et al. [77], that some bacteria, especially Bacillus, etc. suppressed the growth of filamentous fungi both in vitro and in vivo by secreting lytic enzymes such as chitinases and glucanases, which digests their walls that are the protecting layer around fungi and killed them. Similarly, Wahyudi et al. [78] demonstrated that Bacillus sp showed mild antifungal activity against Fusarium sp. Joshi et al. [79] illustrated that Bacillus megaterium showed $47 \%$ inhibition against Fusarium oxysporum.

Antifungal activity of cobalt oxide nanoparticles formed from bacteria fungi and plant extracts demonstrated that these nanoparticles did not show any pronounced activity. However, nanoparticles formed from methanolic extract of plants inhibited the growth of Fusarium moniliforme. The nanoparticles synthesized from rhizobacteria inhibited the growth of Fusarium solani, which may be attributed to the smaller size of these nanoparticles compared to those synthesized from plant extracts and fungi. Size and shape of nanoparticles and methods of their preparation and their interaction with media and stabilizers are responsible for fascinating properties of nanoparticles. However, to obtain good nanoparticle-controlled synthesis application is a key challenge $[80,81]$.

\section{Conclusions}

Bacillus subtilis, Fusarium oxysporum, and methanolic and water extracts of Aerva javanica have potential for the oxidation of cobalt-to-cobalt oxide. XRD confirmed that nanoparticles synthesized via bacteria $(31.2 \mathrm{~nm})$ were smaller than those synthesized from fungus and plant extracts. For the synthesis of nanoparticles from microbes, the bacteria should bear resistance to the metal used. Plants contain many phytochemicals (terpenoids, flavones, ketones, aldehydes, amide, carboxylic acids, etc.) that may be helpful in reduction of metal ions into nanoparticles. Hence synthesis of nanoparticles from plants may be easier and the synthesized nanoparticles may possibly also be more potent as biocontrol agents. The size of nanoparticles being dependent on $\mathrm{pH}$ and incubation time and temperature hence their action may also differ under different growing conditions and abiotic and biotic stresses. The rhizobacterial isolate Bacillus subtilis (N1CI) and methanolic extract of Aerva javanica and Fusarium oxysporum could be used in industry for the sustainable, economical, and environment-friendly synthesis of cobalt oxide nanoparticles.

Author Contributions: Conceptualization, A.B. and N.K.; methodology, N.M., A.B. and T.M.; software, N.K. validation, N.M. and T.M.; formal analysis, T.M.; investigation, A.B., N.K. and T.M.; resources, N.K.; data curation, N.M. writing-original draft preparation, N.M., A.B. and T.M.; writing-review and editing, N.K. supervision A.B. and N.K.; funding acquisition, N.K. All authors have read and agreed to the published version of the manuscript.

Funding: This research received no external funding.

Conflicts of Interest: The authors declare no conflict of interest.

\section{References}

1. Ahmad, A.; Mukherjee, P.; Senapati, P.; Mandal, D.; Khan, M.I.; Umar, R.K.; Santry, M. Extracellular biosynthesis of silver nanoparticles using the fungus Fusarium oxysporum. Colloids Surf. B Biointerfaces 2003, 28, 313-318. [CrossRef]

2. Amany, A.; Kheshen, E.; Sanaa, F.; Rab, G.E. Effect of reducing and protecting agents on size of silver nanoparticles and their anti-bacterial activity. J. Der Pharm. Chem. 2012, 4, 53-65.

3. Chandran, S.P.; Chaudhary, M.; Pasricha, R.; Ahmad, A.; Sastry, M. Synthesis of Gold Nanotriangles and Silver Nanoparticles Using Aloe vera Plant Extract. J. Biotechnol. Prog. 2006, 22, 577-583. [CrossRef]

4. Chen, K.L.; Elimelech, M. Influence of humic acid on the aggregation kinetics of fullerene (C60) nanoparticles in monovalent and divalent electrolyte solutions. J. Colloid Interface Sci. 2007, 309, 126-134. [CrossRef]

5. Joerger, R.; Klaus, T.; Granqvist, C.G. Biologically produced silver-carbon composite materials for optically functional thin-film coatings. J. Adv. Mater. 2000, 12, 407-409. [CrossRef]

6. Dimkpa, C.; Wein, T.; Asch, F. Plant-rhizobacteria interactions alleviate abiotic stresses conditions. Plant Cell Environ. 1997, 32, 1682-1694. [CrossRef] [PubMed] 
7. Prathna, T.C.; Lazar, M.N.; Chandrasekaran, R.M.; Mukherjee, A. Biomimetic Synthesis of Nanoparticles: Science, Technology E Applicability; Mukherjee, A., Ed.; InTechOpen: London, UK, 2010.

8. Khan, N.; Bano, A. Role of plant growth promoting rhizobacteria and Ag-nano particle in the bioremediation of heavy metals and maize growth under municipal wastewater irrigation. Int. J. Phytorem. 2016, 18, 211-221. [CrossRef]

9. Gu, H.; Ho, E.; Tong, L.; Wang, X. Presenting vancomycin on nanoparticles to enhance antimicrobial activities. J. Nano 2003, 9 , 1261-1263. [CrossRef]

10. Hajipour, A.R.; Ruoho, A.R. Oxidation of thiols to the corresponding symmetric disulfides with benzyltriphenylphosphonium peroxodisulfate (btppd) under nonaqueous conditions. Phosphorus Sulfur Silicon Relat. Elem. 2003, 178, 1277-1281. [CrossRef]

11. Niraimathi, K.L.; Sudha, V.; Lavanya, R. Biosynthesis of silver nanoparticles using Alternantherasessilis (Linn.) extract and their antimicrobial, antioxidant activities. J. Colloids Surf. Biointerfaces 2013, 102, 288-291. [CrossRef] [PubMed]

12. Patil, S.P.; Rane, P.M. Psidium guajava leaves assisted green synthesis of metallic nanoparticles: A review. Beni-Suef Univ. J. Basic Appl. Sci. 2020, 9, 60. [CrossRef]

13. Hennebel, T.; Gusseme, B.D.; Boon, N.; Verstraete, W. Biogenic metals in advanced water treatment. J. Trends Biotechnol. 2009, 27, 90-98. [CrossRef] [PubMed]

14. Alsamhary, K.I. Eco-friendly synthesis of silver nanoparticles by Bacillus subtilis and their antibacterial activity. Saudi J. Biol. Sci. 2020, 27, 2185-2191. [CrossRef]

15. Birla, S.S.; Gaikwad, S.C.; Gade, A.K.; Rai, M.K. Rapid synthesis of silver nanoparticles from Fusarium oxysporum by optimizing physicocultural conditions. Sci. World J. 2013, 2013, 796018. [CrossRef]

16. Naimi-Shamel, N.; Pourali, P.; Dolatabadi, S. Green synthesis of gold nanoparticles using Fusarium oxysporum and antibacterial activity of its tetracycline conjugant. J. Mycol. Med. 2019, 29, 7-13. [CrossRef] [PubMed]

17. Ingle, A.; Gade, A.; Pierrat, S.; Sonnichsen, C.; Rai, M. Mycosynthesis of silver nanoparticles using the fungus Fusarium acuminatum and its activity against some human pathogenic bacteria. J. Curr. Nano Sci. 2008, 4, 141-144. [CrossRef]

18. Ahmad, Z.; Pandey, R.; Sharma, S.; Khuller, G.K. Alginate nanoparticles as antituberculosis drug carriers: Formulation development, pharmacokinetics and therapeutic potential. Ind. J. Chest Dis. Allied Sci. 2005, 48, 171-176.

19. Das, S.K.; Das, A.R.; Guha, A.K. Gold Nanoparticles: Microbial Synthesis and Application in Water Hygiene Management. J. Langmuir 2009, 12, 9337-11468. [CrossRef]

20. Khan, N.; Bano, A. Effects of exogenously applied salicylic acid and putrescine alone and in combination with rhizobacteria on the phytoremediation of heavy metals and chickpea growth in sandy soil. Int. J. Pphytorem. 2018, 20, 405-414. [CrossRef]

21. Wani, I.A.; Ahmad, T. Size and shape dependant antifungal activity of gold nanoparticles: A case study of Candida. Colloids Surf. B Biointerfaces 2013, 101, 162-170. [CrossRef]

22. Liu, J.; Qiao, S.Z.; Hu, Q.H.; Lu, G.Q. Magnetic nanocomposites with mesoporous structures, synthesis and applications. Small 2011, 7, 425-443. [CrossRef]

23. Kalimuthu, K.; Babu, R.S.; Venkataraman, D.; Bilal, M.; Gurunathan, S. Biosynthesis of silver nanocrystals by Bacillus licheniformis. J. Colloids Surf. B Biointerfaces 2008, 65, 150-153. [CrossRef] [PubMed]

24. Klaus, T.; Joerger, R.; Olssonand, E.; Granqvist, C.G. Silver based crystalline nanoparticles, microbially fabricated. Proc. Natl. Acad. Sci. USA 1999, 96, 13611-13614. [CrossRef] [PubMed]

25. Gade, A.; Ingle, A.; Whiteley, C.; Rai, M. Mycogenic metal nanoparticles: Progress and applications. Biotechnol. Lett. 2010, 32, 593-600. [CrossRef] [PubMed]

26. Li, J.; Kuang, D.; Feng, Y.; Zhang, F.; Xu, Z.; Liu, M.; Wang, D. Green synthesis of silver nanoparticles-graphene oxide nanocomposite and its application in electrochemical sensing oftryptophan. Biosens. Bioelectron. 2013, 42, 198-206. [CrossRef]

27. Popescu, M.; Velea, A.; Lőrinczi, A. Biogenic production of nanoparticles. Dig. J. Nanomater. Biostruct. (DJNB) 2010, 5, 1035-1040.

28. Man, Y.; Wang, B.; Wang, J.; Slaný, M.; Yan, H.; Li, P.; El-Naggar, A.; Shaheen, S.M.; Rinklebe, J.; Feng, X. Use of biochar to reduce mercury accumulation in Oryza sativa L: A trial for sustainable management of historically polluted farmlands. Environ. Int. 2021, 153, 106527. [CrossRef]

29. Rastogi, A.; Singh, P.; Haraz, F.A.; Barhoum, A. Biological synthesis of nanoparticles: An environmentally benign approach. In Fundamentals of Nanoparticles; Elsevier BV: Amsterdam, The Netherlands, 2018; pp. 571-604.

30. Kumari, M.; Pandey, S.; Giri, V.P.; Bhattacharya, A.; Shukla, R.; Mishra, A.; Nautiyal, C. Tailoring shape and size of biogenic silver nanoparticles to enhance antimicrobial efficacy against MDR bacteria. Microb. Pathog. 2017, 105, 346-355. [CrossRef]

31. Wang, Y.; Zhu, J.; Yang, X.; Lu, L.; Wang, X. Preparation of NiO nanoparticles and their catalytic activity in the thermal decomposition of ammonium perchlorate. Thermochim. Acta 2005, 437, 106-109. [CrossRef]

32. Khalil, A.T.; Ovais, M.; Ullah, I.; Ali, M.; Shinwari, Z.K.; Maaza, M. Physical properties, biological applications and biocompatibility studies on biosynthesized single phase cobalt oxide (Co3O4) nanoparticles via Sageretia thea (Osbeck.). Arab. J. Chem. 2020, 13, 606-619. [CrossRef]

33. Rastogi, A.; Zivcak, M.; Sytar, O.; Kalaji, H.M.; He, X.; Mbarki, S.; Brestic, M. Impact of Metal and Metal Oxide Nanoparticles on Plant: A Critical Review. Front. Chem. 2017, 5, 78. [CrossRef] [PubMed]

34. Jiang, J.; Oberdörster, G.; Biswas, P. Characterization of size, surface charge, and agglomeration state of nanoparticle dispersions for toxicological studies. J. Nanopart. Res. 2009, 11, 77-89. [CrossRef]

35. Chattopadhyay, S.; Dash, S.K.; Tripathy, S.; Das, B.; Mandal, D.; Pramanik, P.; Roy, S. Toxicity of cobalt oxide nanoparticles to normal cells; an in vitro and in vivo study. Chem. Biol. Interact. 2015, 226, 58-71. [CrossRef] [PubMed] 
36. Yang, J.; Cao, W.; Rui, Y. Interactions between nanoparticles and plants: Phytotoxicity and defense mechanisms. J. Plant Interact. 2017, 12, 158-169. [CrossRef]

37. Aslani, F.; Bagheri, S.; Muhd Julkapli, N.; Juraimi, A.S.; Hashemi, F.S.G.; Baghdadi, A. Effects of engineered nanomaterials on plants growth: An overview. Sci. World J. 2014, 2014, 641759. [CrossRef] [PubMed]

38. Singh, P.; Garg, A.; Pandit, S.; Mokkapati, V.R.S.S.; Mijakovic, I. Antimicrobial Effects of Biogenic Nanoparticles. Nanomaterials 2018, 8, 1009. [CrossRef] [PubMed]

39. Kousar, B.; Bano, A.; Khan, N. PGPR Modulation of Secondary Metabolites in Tomato Infested with Spodoptera litura. Agronomy 2020, 10, 778. [CrossRef]

40. Kuppusamy, P.; Yusoff, M.M.; Maniam, G.P.; Govindan, N. Biosynthesis of metallic nanoparticles using plant derivatives and their new avenues in pharmacological applications-An updated report. Saudi Pharm. J. 2016, 24, 473-484. [CrossRef]

41. Bérdy, J. Bioactive Microbial Metabolites. J. Antibiot. 2005, 58, 1-26. [CrossRef]

42. Vahabi, K.; Mansoori, G.A.; Karimi, S. Biosynthesis of silver nanoparticles by fungus Trichoderma reesei. Insci. J. 2011, 1, 65-79. [CrossRef]

43. Khan, N.T.; Khan, M.J.; Jameel, J.; Jameel, N.; Rheman, S.U.A. An overview: Biological organisms that serves as nanofactories for metallic nanoparticles synthesis and fungi being the most appropriate. Bioceram Dev. Appl. 2017, 7, 101. [CrossRef]

44. Boroumand Moghaddam, A.; Namvar, F.; Moniri, M.; Azizi, S.; Mohamad, R. Nanoparticles Biosynthesized by Fungi and Yeast: A Review of Their Preparation, Properties, and Medical Applications. Molecules 2015, 20, 16540-16565. [CrossRef] [PubMed]

45. Singh, J.; Vishwakarma, K.; Ramawat, N.; Rai, P.; Singh, V.K.; Mishra, R.K.; Kumar, V.; Tripathi, D.K.; Sharma, S. Nanomaterials and microbes' interactions: A contemporary overview. 3 Biotech 2019, 9, 68. [CrossRef]

46. Rajkumari, J.; Magdalane, C.M.; Siddhardha, B.; Madhavan, J.; Ramalingam, G.; Al-Dhabi, N.A.; Arasu, M.V.; Ghilan, A.K.M.; Duraipandiayan, V.; Kaviyarasu, K. Synthesis of titanium oxide nanoparticles using Aloe barbadensis mill and evaluation of its antibiofilm potential against Pseudomonas aeruginosa PAO1. J. Photochem. Photobiol. B Biol. 2019, 201, 111667. [CrossRef]

47. Wang, L.; Hu, C.; Shao, L. The antimicrobial activity of nanoparticles: Present situation and prospects for the future. Int. J. Nanomed. 2017, 12, 1227-1249. [CrossRef] [PubMed]

48. Zhang, L.; Pornpattananangkul, D.; Hu, C.-M.; Huang, C.-M. Development of Nanoparticles for Antimicrobial Drug Delivery. Curr. Med. Chem. 2010, 17, 585-594. [CrossRef]

49. Mukherjee, B.; Santra, K.; Pattnaik, G.; Ghosh, S. Preparation, characterization and in-vitro evaluation of sustained release pro-tein-loaded nanoparticles based on biodegradable polymers. Int. J. Nanomed. 2008, 3, 487-496. [CrossRef] [PubMed]

50. Khan, N.; Bano, A.; Zandi, P. Effects of exogenously applied plant growth regulators in combination with PGPR on the physiology and root growth of chickpea (Cicer arietinum) and their role in drought tolerance. J. Plant Interact. 2018, 13, 239-247. [CrossRef]

51. Singh, P.; Kim, Y.-J.; Zhang, D.; Yang, D.-C. Biological Synthesis of Nanoparticles from Plants and Microorganisms. Trends Biotechnol. 2016, 34, 588-599. [CrossRef] [PubMed]

52. Steel, K.J. The oxidase reaction as a toxic tool. Microbiology 1961, 25, 297-306.

53. Choudhary, M.I.; Parveen, Z.; Jabbar, A.; Ali, I. Antifungal steroidal lactones from Withania coagulance. Phytochemistry 1995, 40, 1243-1246. [CrossRef]

54. Khan, N.; Bano, A. Exopolysaccharide producing rhizobacteria and their impact on growth and drought tolerance of wheat grown under rainfed conditions. PLoS ONE 2019, 14, e222302. [CrossRef]

55. Cheng, S.-C.; Bhat, S.M.; Lee, C.-W.; Shiea, J. Thin layer chromatography combined with electrospray ionization mass spectrometry for characterizing herbal compounds. Int. J. Mass Spectrom. 2018, 434, 264-271. [CrossRef]

56. MacFaddin, J.F. Biochemical test for identification of Medicinal Bacteria. Macro and micronutrients in alkaline soils. Commun. Soil Sci. Plant Anal. 1980, 8, 195-207.

57. Karumi, Y.; Onyeyili, P.A.; Ogugbuaja, V.O. Identification of Active Principles of M. balsamina (Balsam Apple) Leaf Extract. J. Med. Sci. 2004, 4, 179-182.

58. Shaw, P.D.; Ping, G.; Daly, S.L.; Cha, C.; Cronan, J.E.; Rinehart, K.L.; Farrand, S.K. Detecting and characterizing N-acyl-homoserine lactone signal molecules by thin-layer chromatography. Proc. Natl. Acad. Sci. USA 1997, 94, 6036-6041. [CrossRef]

59. Lou, X.W.; Deng, D.; Lee, J.Y.; Feng, J.; Archer, L.A. Self-supported formation of needlelike Co3O4 nanotubes and their application as lithium-ion battery electrodes. J. Adv. Mater. 2008, 20, 258-262. [CrossRef]

60. Mandelbrot, B.B. The Fractal Geometry of Nature; Freeman: San Francisco, CA, USA, 1982.

61. Matsushita, M. Experimental observations of aggregations. In The Fractal Approach to Heterogeneous Chemistry: Surfaces, Colloids, Polymers; Avnir, D., Ed.; John Wiley, Sons: New York, NY, USA, 1989; pp. 161-179.

62. Mohanpuria, P.; Rana, N.K.; Yadav, S.K. Biosynthesis of nanoparticles, technological concepts and future applications. J. Nanopart. Res. 2008, 10, 507-517. [CrossRef]

63. He, S.; Guo, Y.; Zhang, S.; Zhang, S.; Wang, J.; Gu, N. Biosynthesis of gold nanoparticles using the bacteria Rhodopseudomonascapsulata. J. Mater. 2007, 61, 3984-3987.

64. Pant, G.; Nayak, N.; Prasuna, R.G. Enhancement of antidandruff activity of shampoo by biosynthesized silver nanoparticles from Solanum trilobatum plant leaf. Appl. Nano Sci. 2012, 3, 431-439. [CrossRef]

65. Parikh, R.Y.; Singh, S.; Prasad, B.L.V.; Patole, M.S.; Sastry, M.; Shouche, Y.S. Extracellular synthesis of crystalline silver nanoparticles and molecular evidence of silver resistance from Morganella sp. towards understanding biochemical synthesis mechanism. ChemBioChem 2008, 9, 1415-1422. [CrossRef] 
66. Durán, N.; Marcato, P.D.; Alves, O.L.; De Souza, G.I.H.; Esposito, E. Mechanistic aspects of biosynthesis of silver nanoparticle by several Fusarium oxysporum strains. J. Nanobiotechnol. 2005, 3, 8. [CrossRef] [PubMed]

67. Qureshi, R.; Bhatti, R.G. Folklore uses of amaranthaceae family from Nara desert, Pakistan. Pak. J. Bot. 2009, 41, $1565-1572$.

68. Khan, N.; Bano, A. Modulation of phytoremediation and plant growth by the treatment with PGPR, Ag nanoparticle and untreated municipal wastewater. Int. J. Phytoremediation 2016, 18, 1258-1269. [CrossRef] [PubMed]

69. Reddy, K.S.; Reddy, V.M. Antimicrobial studies on the leaves of Aerva javanica. J. Pharm. Res. 2009, 2, $1259-1261$.

70. Retchkiman-Schabes, P.S.; Canizal, G.; Becerra-Herrera, R.; Zorrilla, R.C.; Liu, H.B.; Ascencio, J.A. Biosynthesis and characterization of Ti/Ni bimetallic nanoparticles. J. Opt. Mater. 2006, 29, 95-99. [CrossRef]

71. Richardson, A.; Chan, B.C.; Crouch, R.D.; Janiec, A.; Chan, B.C.; Crouch, R.D. Synthesis of silver nanoparticles: An undergraduate laboratory using green approach. Chem. Educ. 2006, 11, 331-333.

72. Shankar, S.S.; Ahmad, A.; Pasricha, R.; Sastry, M. Bioreduction of chloroaurate ions by geranium leaves and its endophytic fungus yields gold nanoparticles of different shapes. J. Mater. Chem. 2003, 13, 1822-1826. [CrossRef]

73. Shankar, S.S.; Ahmad, A.; Sastry, M. Geranium Leaf Assisted Biosynthesis of Silver Nanoparticles. J. Biotechnol. Prog. 2003, 19, 1627-1631. [CrossRef]

74. Yang, X.; Chung, E.; Johnston, I.; Ren, G.; Cheong, Y.-K. Exploitation of Antimicrobial Nanoparticles and Their Applications in Biomedical Engineering. Appl. Sci. 2021, 11, 4520. [CrossRef]

75. Windless, C.E. Current status of Fusarium Taxonomy. Phytopathology 1991, 81, 1048-1051.

76. Armstrong, G.M.; Armostrong, J.K.A. Formae Speciales and Races of Fusarium Oxysporum Causing Wilt Diseases; Pennsylvania State University Press: University Park, PA, USA, 1981.

77. Céspedes, C.L.; El-Hafidi, M.; Pavon, N.; Alarcon, J. Antioxidant and cardioprotective activities of phenolic extracts from fruits of Chilean blackberry Aristotelia chilensis (Elaeocarpaceae), Maqui. Food Chem. 2008, 107, 820-829. [CrossRef]

78. Svanström, Å.; Boveri, S.; Boström, E.; Melin, P. The lactic acid bacteria metabolite phenyllactic acid inhibits both radial growth and sporulation of filamentous fungi. BMC Res. Notes 2013, 6, 464. [CrossRef]

79. Wahyudi, A.T.; Astuti, R.P.; Widyawati, A.; Mery, A.; Nawangsih, A.A. Characterization of Bacillus sp. strains isolated from rhizosphere of soybean plants for their use as potential plant growth for promoting rhizobacteria. J. Microbiol. Antimicrob. 2011, 3 , 34-40.

80. Joshi, S.; Bharucha, C.; Desai, A.J. Production of biosurfactant and antifungal compound by fermented food isolate Bacillus subtilis 20B. Bioresour. Technol. 2008, 99, 4603-4608. [CrossRef] [PubMed]

81. Mothana, R.A.A.; Gruenert, R.; Bednarski, P.J.; Lindequist, U. Evaluation of the in vitro anticancer, antimicrobial and antioxidant activities of some Yemeni plants used in folk medicine. Die Pharm. 2009, 64, 260-268. 